\title{
Tissue cultures of blood-sucking Arthropods and their use for the cultivation of Viruses and Rickettsiae
}

\author{
par J. REHACEK \\ Institute of Virology, Slovak Academy of Sciences, Bratislava, Tchécoslovaquie
}

\begin{abstract}
Résumé
Le développement des cultures de tissus des Arthropodes hématophages et leur utilisation pour l'étude des microorganismes a grandement progressé depuis ces dernières années, principalement grâce à l'amélioration des techniques. L'établissement de plusieurs lignées continues de cellules de moustiques a aidé les virologues, en fournissant un milieu pour l'étude des réplications de virus.

Les cultures de tissus des Arthropodes hématophages sont issues de tiques, poux, punaises, puces, moustiques et mouches.

Tiques: Weyer, 1952, essaie d'utiliser des cultures d'organes de Rhipicephalus pour la culture de rickettsies mais sans succès. Rehacek, 1958 et Rehacek et Pesek, 1960 cultivent le virus EEE sur des cultures d'organes de différentes espèces de tiques et obtiennent une multiplication virale sur les tissus conjonctifs et de l'hypoderme. Hoffmann et Köhler, 1968, observent que des cultures d'organes de tiques in vitro restent vivantes plus de 2 mois.

Des cultures primaires de différentes espèces de tiques prises à l'état adulte à l'intérieur de nymphes gorgées sont décrites par Rehacek, 1958, 1962 et Martin et Vidler, 1962. Plus tard, la quantité d'acides aminés et de sucre utilisée par les cellules in vitro est déterminée par Rehacek et Brzostowski, $1969 b$; Varma et Pudnoy, $1969 a$. Ces cultures sont utilisées avec succès pour la multiplication de virus divers transmis dans la nature par les tiques (Rehacek,
\end{abstract}


1965 b ; Yunker et Cory, 1967 ; Rehacek et al., 1969). Il a été montré qu'une souche de laboratoire du virus de l'encéphalite prélevé sur tiques se multiplie mieux dans les cellules de tiques que dans les cultures d'embryons de poulet ou par injection intracérébrale dans la souris. Les virus d'origines naturelles poussent également bien dans ces trois environnements (Rehacek et Kozuch, 1964, 1969). Les rickettsies pathogènes pour les vertébrés se multiplient in vitro dans les cellules de Hyalomma dromedarii (Rehacek et Brezina, 1964 ; Rehacek et al., 1968).

Poux, punaises, puces: Nauck et Weyer, 1941 utilisent des morceaux d'organes de poux, punaises et puces pour la culture de plusieurs rickettsies. Le seul organe ayant donné des résultats est l'estomac de pou, qui a pu être maintenu vivant pendant 40 jours. La croissance des rickettsies a été mise en évidence dans ces cultures d'estomac de poux.

Bien que les cultures d'organes aussi bien que les cultures primaires de Heteroptera soient réalisées (Vago et Flandre, 1963 ; Varma et Pudney, 1967), elles n'ont pas encore été utilisées pour l'étude des virus et des rickettsies.

Mouches : Trager, 1959 établit des cultures primaires de Glossina palpalis. Ces cultures sont utilisées pour la multiplication des Trypanosomes.

Moustiques: Parmi les cultures de cellules d'Arthropodes, celles de moustiques ont retenu l'attention de façon primordiale.

Des cultures d'organes, principalement des organes digestifs, sont maintenus in vitro pour la culture de Plasmodia (Ball, 1947, 1948; Schneider, 1968) et des fragments d'autres organes sont maintenus pour la culture de certains arbovirus (Trager, 1938; Haines, 1958). Les organes maintenus in vitro restent vivants comme le montrent les contractions. Des ovaires ont été maintenus pendant 80 jours (Gubler, 1968).

Les cultures de cellules primaires sont établies à partir de larves (Peleg et Trager, 1963; Peleg, 1965; Johnson, 1969), de pupes (Sweet et Dupree, 1968; Johnson, 1969), d'adultes (Gubler, 1968) et de tissus embryonnaires (Peleg, 1966; Singh et Bhat, 1969). La multiplication des cultures donne lieu à trois formations: tapis cellulaire, grandes vésicules sphériques creuses et longs tubes creux (Bhat et Singh, 1969). Les arbovirus West Nile, EEE, Semliki Forest (Peleg et Trager, 1963; Peleg, 1968) et les virus d'encéphalites japonaises (Fujita et al., 1968) poussent dans ces cultures de cellules.

La multiplication du virus de l'encéphalite japonaise est mise aussi en évidence par l'immunofluorescence. Johnson, 1969, trouve que la multiplication du VEE et du virus EEE dans des cultures type Maintland dérivées de larves et de pupes stériles hachées sont dépendantes de la température d'incubation, de l'agitation à la- 
quelle les cellules sont soumises pendant l'incubation et de la concentration de virus. Deux lignées du VEE après 10 passages dans les tissus larvaires (souche virulente) et 5 passages (souche moins virulente) ne présentent aucun changement de virulence pour la souris ni de changement de taille des plages en culture de cellules.

L'établissement de la première lignée cellulaire continue d'insecte (Grace, 1962) à partir des papillons Antheraea et des moustiques Aedes aegypti (1966) met en évidence la possibilité d'obtention de telles lignées cellulaires à partir d'invertébrés et ouvre de nouvelles voies dans la recherche des cultures in vitro d'Arthropodes. Par la suite, des lignées cellulaires ont été obtenues à partir de tissus embryonnaires de moustiques (Peleg, 1968), de tissus larvaires (Singh, 1967 ; Varma et Pudney, 1969 b), de nymphes (Singh, 1967) de différentes espèces de moustiques Aedes.

Un large emploi des lignées cellulaires de Grace était limité par la difficulté d'obtenir de l'hémolymphe d'insecte. Ceci a été surmonté par l'adaptation des cellules à un milieu sans hémolymphe [Sweet et Dupree, 1968; Nagle, 1967; Suitor, 1968 (pers. com.)]. Suitor et al., 1966, réussit à cloner des cellules en forme d'épingle à partir de la lignée cellulaire de Grace. Stanley et Vaughn, 1967, montrent que les lignées cellulaires ne tolèrent pas la Fungizone, préparation commerciale d'amphotéricine B.

La lignée de cellules de Grace est très utilisée pour la culture de certains arbovirus. Converse et Nagle, 1967, mettent en évidence la multiplication du virus de la fièvre jaune et Rehacek, 1968, observe la multiplication des virus West Nile, de lencéphalite japonaise, de l'encéphalite de la vallée Murray et du virus Kunjin. Rehacek, $1968 b$, réussit à établir un état porteur avec les virus de l'encéphalite japonaise. Filshie et Rehacek, 1968, décrivent la morphologie et la réplication de ces deux virus au moyen du microscope électronique. On découvre que les cellules de Grace sont contaminées par un virus latent inconnu d'insecte qui se multiplie quand les cellules sont infectées avec le virus de l'encéphalite japonaise Filshie et al., 1967). Peleg, $1968 a$, $b$, observe la multiplication des virus EEE, West Nile et de la maladie de la forêt Semliki dans les lignées de cellules d'embryons d'Aedes aegypti. Les lignées continues d'Aedes albopictus et d'Aedes aegypti réalisées par Singh, 1967, sont utilisées par Singh et Paul, 1968, pour la multiplication de différents arbovirus. Ces auteurs observent des différences mar. quées dans la multiplication des virus dans ces deux lignées cellu. laires. L'effet cytopathologique marqué mis en évidence par les cytolyses, la formation de grandes masses syncitiales et les cellules géantes multinuclées sont décrites au cours de l'infection avec les virus de l'encéphalite japonaise, de West Nile et de la dengue dans les cellules d'Aedes albopictus seulement (Paul et al., 1969). Cette lignée cellulaire supporte aussi la multiplication du virus de la Fièvre du Colorado (Yunker et Cory, 1969). Banerjee 
et Singh, 1968, réussissent à établir un état porteur avec les virus de l'encéphalite japonaise, de West Nile, de Chikungunya avec la même lignée cellulaire.

Les différents aspects de l'application pratique des cultures de tissus d'Arthropodes pour la multiplication des virus et des rickettsies sont discutés.

\section{Summary}

The development of tissue cultures of blood-sucking arthropods and their use for studies with microorganisms has progressed greatly during the last few years. It has been achieved mainly by basic improvement of cultivation techniques. The establishment of many cell lines from mosquitoes aided virologists by providing a medium for studies of virus replication.

Of the haematophagous arthropods, tissue cultures have been derived from ticks, lice, bugs, fleas, mosquitoes and flies.

Ticks: Weyer, 1952, attempted to use organ cultures of Rhipicephalus ticks for the cultivation of rickettsiae without success. Rehacek, 1958, and Rehacek and Pesek, 1960, cultivated EEE virus on organ cultures of different tick species and accomplished the propagation of virus on connective tissue together with hypodermis. Hoffmann and Köhler, 1968, observed the viability of tick organ cultures in vitro for more than 2 months.

Primary cultures derived from developing adults within engorged nymphs of different tick species were described by Rehacek, 1958, 1962 and Martin and Vidler, 1962. Later the uptake of amino acids and sugars by the cells in vitro was determined by Rehacek and Brzostowski, $1969 \mathrm{~b}$; Varma and Pudney, $1969 a$. These cultures were used successfully for the propagation of various viruses transmitted in nature by ticks (Rehacek, $1965 \mathrm{~b}$; Yunker and Cory, 1967; Rehacek et al., 1969). A laboratory strain of tickborne encephalitis virus was found to multiply better in tick cells than in chick embryo cultures or intracerebrally injected mice. Viruses from natural sources grew equally well in all three media (Rehacek and Kozuch, 1964, 1969). Rickettsiae pathogenic for vertebrates were found to multiply in Hyalomma dromedarii cells in vitro (Rehacek and Brezina, 1964 ; Rehacek et al., 1968).

Lice, bugs and fleas: Nauck and Weyer, 1941, used minced organs from lice, bugs and fleas for the cultivation of several rickettsiae. The only susceptible organ was found to be louse sto. mach which was maintained for 40 days. Growth of rickettsiae was demonstrated in these louse stomach organ cultures.

Although the organ culture as well as primary cell cultures of Heteroptera were developed (Vago and Flandre, 1963 ; Varma and 
Pudney, 1967) they have not yet been used for virus and rickettsial studies.

Flies: Primary cultures were established from Glossina palpalis by Trager, 1959. These cultures have been used for the propagation of Trypanosomes.

Mosquitoes: Mosquito cultures have received primary attention in studies of arthropod cell cultures by most investigators in this research area.

Organ cultures, primarily digestive organs, have been maintained in vitro for the cultivation of Plasmodia (Ball, 1947, 1948 ; Schneider, 1968) and fragments of other organs maintained for cultivation of certain arboviruses (Trager, 1938; Haines, 1958). The organs maintained in vitro remain viable as evidenced by contractibility. Ovary has been maintained for 80 days (Gubler, 1968).

Primary cell cultures have been established from larvae (Peleg and Trager, 1963 ; Peleg, 1965 ; Johnson, 1969), pupae (Sweet and Dupree, 1968 ; Johnson, 1969), adult tissue (Gubler, 1968) and from embryonal tissues (Peleg, 1966; Singh and Bhat, 1969). Growth of cultures have been characterized by three types: the establishment of a cell sheet, large hollow spherical vesicles, and elongate hollow tubes (Bhat and Singh, 1969). The arboviruses, West-Nile, EEE, Semliki Forest (Peleg and Trager, 1963; Peleg, 1968), and Japanese Encephalitis viruses (Fujita et al., 1968) were grown in these cell cultures. The propagation of Japanese encephalitis virus was also described by immunofluorescence. Johnson, 1969, found the multiplication of VEE and EEE viruses in Maintland type cultures derived from minced germ-free larvae and pupae to be dependent on the temperature of incubation, shaking of cells during incubation, and on the virus concentration used. Two strains of VEE virus passed in larval tissue ten times (virulent strain) and five times (less virulent strain) caused no changes in virulence for mice or in plaque size in cell culture.

The establishment of the first insect cell lines (Grace, 1962) from Antheraea butterflies and Aedes aegypti mosquitoes (1966) demonstrated the possibility of deriving cell lines from invertebrates and opened new areas of in vitro arthropod research. Further cell lines have been derived from embryonic mosquito tissue (Peleg, 1968) and from larval tissue (Singh, 1967; Varma and Pudney, $1969 \mathrm{~b}$ ), from pupae (Singh, 1967) from different species of Aedes mosquitoes.

Wider use of Grace's cell lines was limited by lack of availability of insect haemolymph. This was overcome by the adaptation of cells to media without haemolymph [Sweet and Dupree, 1968; Nagle, 1967 ; Suitor, 1968 (pers. com.)]. Suitor, et al., 1966, succeeded in cloning spindle-shaped cells from Grace's cell line. 
Stanley and Vaughn, 1967, found this cell line to be intolerant to Fungizone, a commercial preparation of the polyene amphotericin B.

Grace's cell line has been used extensively for the cultivation of certain arboviruses. Converse and Nagle, 1967, demonstrated the propagation of Yellow Fever virus and Rehacek, $1968 a$, observed the multiplication of West Nile, Japanese Encephalitis, Murray Valley Encephalitis and Kunjin viruses. Rehacek, $1968 b$, succeeded in the establishment of a carrier state with Murray Valley Encephalitis and Japanese Encephalitis viruses. Filshie and Rehacek, 1968, described the morphology and replication of both viruses by means of electron microscopy. It was discovered that Grace's cells were contaminated with an unknown latent insect virus which multiplied following the infection with Japanese Encephalitis virus Filshie et al., 1967). Peleg, $1968 a, b$, observed the multiplication of EEE, West-Nile and Semliki Forest disease viruses in the Aedes aegypti embryo cell line. The cell line from Aedes albopictus and Aedes aegypti derived by Singh, 1967 has been used by Singh and Paul, 1968, for the propagation of different arboviruses. These authors observed marked differences in propagation among viruses in both cell lines. Marked cytopathic effect demonstrated by cytolysis, formation of large syncytial masses and multinucleated giant cells has been described following infection with Japanese Encephalitis, West-Nile and Dengue viruses in Aedes albopictus cells only (Paul et al., 1969). This cell line also supported the propagation of Colorado Tick Fever virus (Yunker and Cory, 1969). Banerjee and Singh, 1968, succeeded in the establishment of a carrier state with Japanese Encephalitis, West-Nile and Chikungunya viruses with the same strain of cells.

Practical application of arthropod tissue cultures for the propagation of viruses and rickettsiae from various aspects is discussed.

The development of tissue cultures of blood-sucking arthropods and their use for studies with microorganisms has progressed greatly during the last few years. It has been achieved mainly by basic improvement of cultivation techniques. The establishment of many cell lines from mosquitoes aided virologists by providing a medium for studies of virus replication.

Of the haematophagous arthropods, tissue cultures have been derived from ticks, lice, bugs, fleas, mosquitoes, and flies.

\section{Tieks.}

The first experiments on maintenance of tick organs in vitro were done by Weyer, 1952 , in an attempt to cultivate rickettsiae. However, he succeeded only in keeping 
the organs viable for a very short time. The uninfected tick organs kept together with infectious louse stomach in vitro did not become infected.

Organ culture as a medium for the cultivation of Eastern equine encephalomyelitis (EEE) virus was used by Rehacek and Pesek, 1960. Various organs of half engorged females Ixodes ricinus, Dermacentor pictus and D. marginatus maintained in test tubes at $25^{\circ} \mathrm{C}$ in TC 199 medium were infected with various doses of virus. The tissues of organs such as ovaries, malpighian tubes, salivary glands and guts manifested an almost identical slightly protective effect on virus in medium in comparison with virus in cell-free medium. The multiplication of virus occurred only in the presence of hypodermis and connective tissues of $D$. pictus and $I$. ricinus ticks, the virus increment being of the order of 4 logarithmic units of TCID $_{50}$ of virus.

The organ and haemolymph cultures of D. pictus and 1 . ricinus females were used for the study of the Coxiella burneti development from its filterable particles. The typical $C$. burneti was found in the tissues of organs after 14 to 16 days in quantities considerably smaller than in ticks injected with the same inoculum (Kordova and Rehacek, 1959).

A series of experiments with the organ cultures of adult Rhipicephalus appendiculatus ticks were performed by Martin and Vidler, 1962, then with organs of Boophilus microplus (Rehacek, 1966, unpublished results) and other several hard tick species (Hoffmann and Köhler, 1968). These experiments demonstrated only a long time survival of different organs as evidenced primarily by contractile or peristaltic movements.

More attention has been paid to primary tick tissue cultures which seem to be a more convenient medium for the cultivation of microorganisms. The method of their establishment was described by Rehacek, 1958, 1962, $1965 a$; Martin and Vidler 1962, Yunker and Cory, 1965, 1967 and Varma and Wallers, 1965. These cultures originate from the developing tissues of adults from engorged nymphs undergoing metamorphosis. The tissues consist of oesophagus, salivary glands, gonadal and other genital tissues, neural ganglion, nerve trunks, muscles and elements of the hypoderm of the preimaginal stage. The cultures are used in the form of an explant of the body content in toto or dispersed to separate cells by mechanical or chemical means, or with both methods. The best results were achieved with the medium composed of the mixture of Eagle's medium (Eagle, 1955), and the medium of Vago and Chastang (Vago and Chastang, 1960), in a ratio of 2: 1 plus 0,1\% of a fraction from dried calf serum (Rehacek, $1965 \mathrm{a}$ ); (the latter component can also be foetal bovine serum) (Varma and Wallers, 1965), and by Martin and Vidler, 1962, which consisted of Hank's balanced salt solution to which the amino acids and vitamins of Eagle's medium and $20 \%$ ox serum were added. Yunker and Cory, 1967, cultivated the viscera of ticks successfully in a medium composed of Lactalbumin hydrolysate in in Hank's balanced salt solution to which $10 \%$ heat inactivated normal rabbit serum, $10 \%$ whole chicken-egg ultrafiltrate and bovine plasma albumin were added. The cells cultivated in these media multiplied very well for a few months, often establishing 
the monolayers on the coverglasses or walls of the containers in which they were cultivated.

The last improvement on the composition of medium was accomplished by Rehacek and Brzostowski, $1969 a$. This is based on the chemical analysis of amino acids, sugars and salts of haemolymph of engorged Boophilus microplus females. Medium was tested on the cells of Rhipicephalus sanguineus ticks and showed growth and viability of cells for nine months. The same authors (Rehacek and Brzostowski, $1969 \mathrm{~b}$ ) described the utilization of the amino acids and sugars in the medium by cells of the same tick species (Fig. 1-4). They observed the uptake of several amino

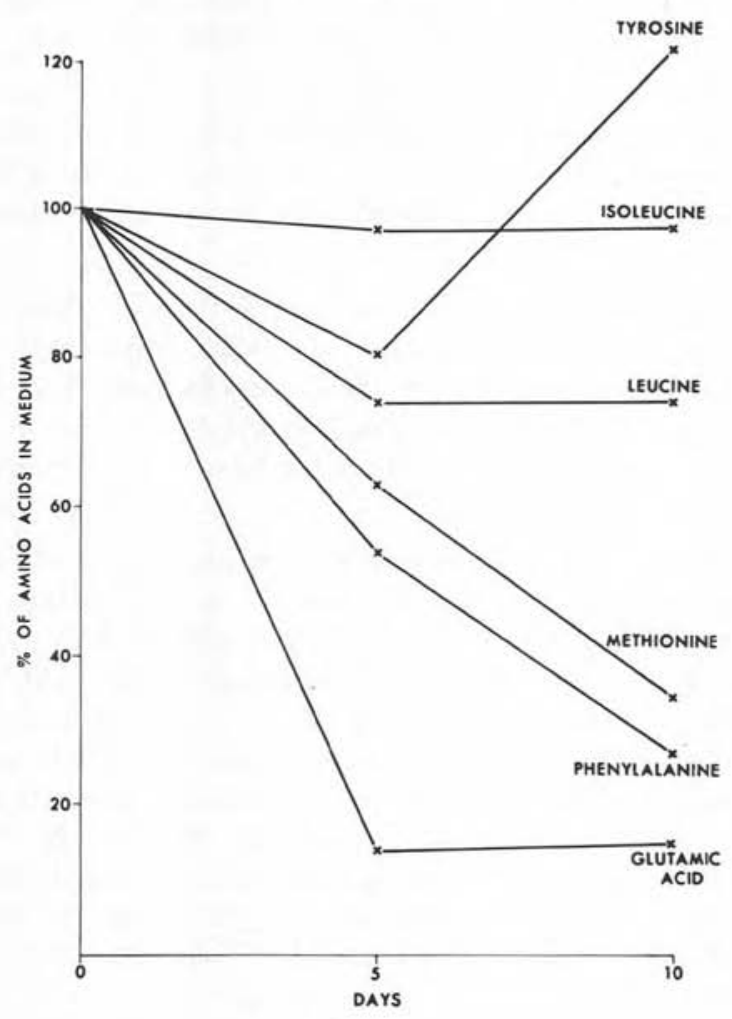

FIG. 1

acids such as leucine, methionine, threonine, phenylalanine, proline, glutamic and aspartic acid to a significant extent while the other amino acids occurring in the medium showed no change in concentration. Both sugars, glucose and inositol, were used by cells in cultures to a great extent ; this being confirmed later by Varma and Pudney, $1969 a$. All these studies were done to further improve the composition of the media. 


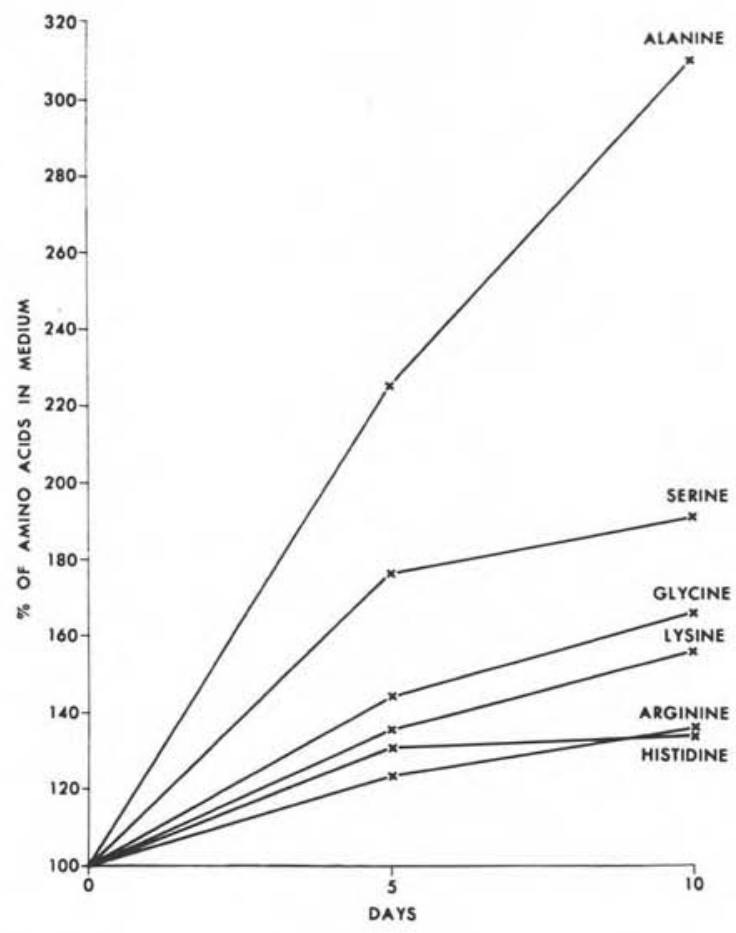

FIG. 2

As a sufficient amount of in vitro tick cells became available (Fig. 5), cultivation experiments of different microorganisms could be tried. It was found that tick-borne encephalitis virus multiplies in tick cells very well (Rehacek, 1962, 1963) (Fig. 6 and 7) and this was an impetus for testing other viruses. For this purpose the cultures of Hyalomma dromedarii ticks were used (Rehacek, $1965 \mathrm{~b}$ ). It was found that of group A arboviruses, Western equine encephalomyelitis, EEE, Sindbis and Semliki Forest viruses multiplied very well in cultures (Fig. 8). The cultivation of group B arboviruses yielded varied results: Langat (TP 21), Japanese encephalitis (JE), St. Louis encephalitis (SLE) and yellow fever viruses multiplied in tick tissue cultures poorly. Kyasanur Forest Disease, Powassan, Omsk haemorrhagic fever, and West Nile viruses multiplied relatively well and tick-borne encephalitis (western type), Russianspring summer encephalitis and louping-ill viruses multiplied excellently (Fig. 9 and 10). The highest titers of the viruses were obtained with small inocula, the virus increment being approximately of the order of 0,5-1 logarithmic units per day. The viruses not belonging to the arbovirus group, such as-EMC, polio, vaccinia, vesicular stomatits, NDV and pseudorabies did not multiply in tick tissue cultures and their titers in samples taken at two days intervals for 8 days of cultivation were practically the 


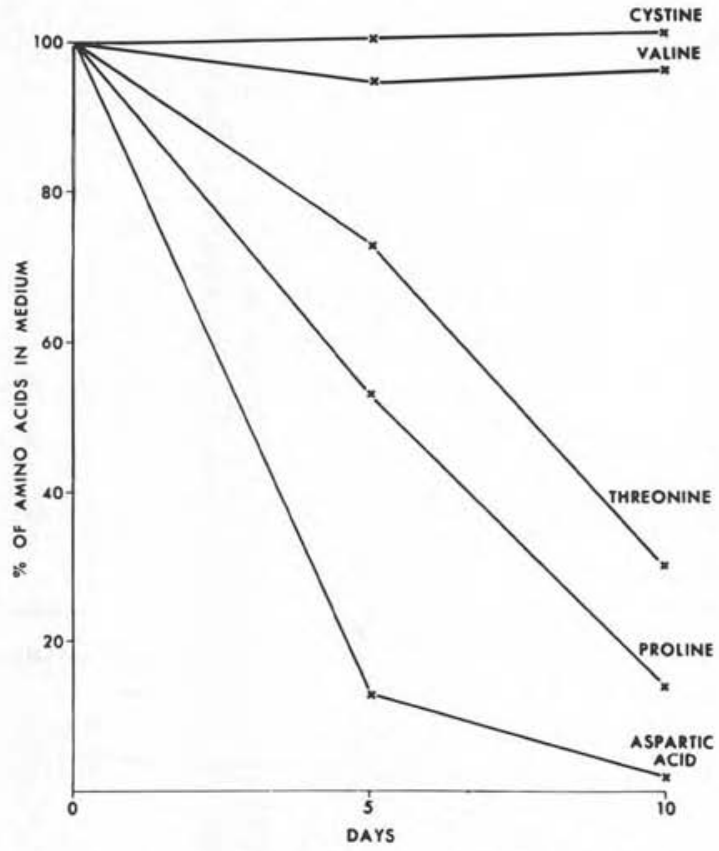

FIG. 1, 2, 3. - Utilization of amino acids by tick cells in vitro

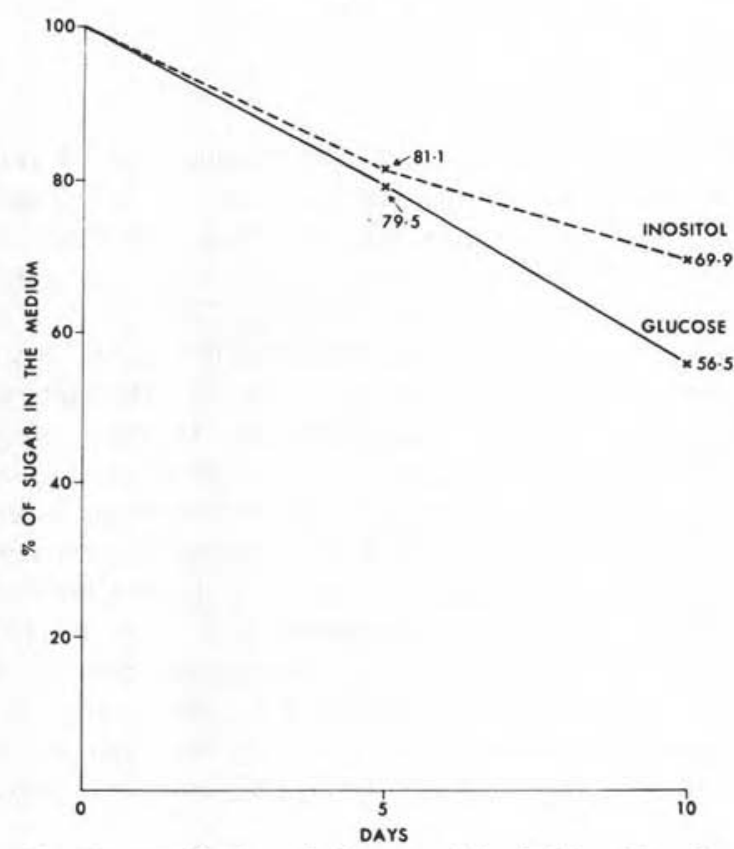

Fig. 4. - Utilization of glucose and inositol by tick cells in vitro 


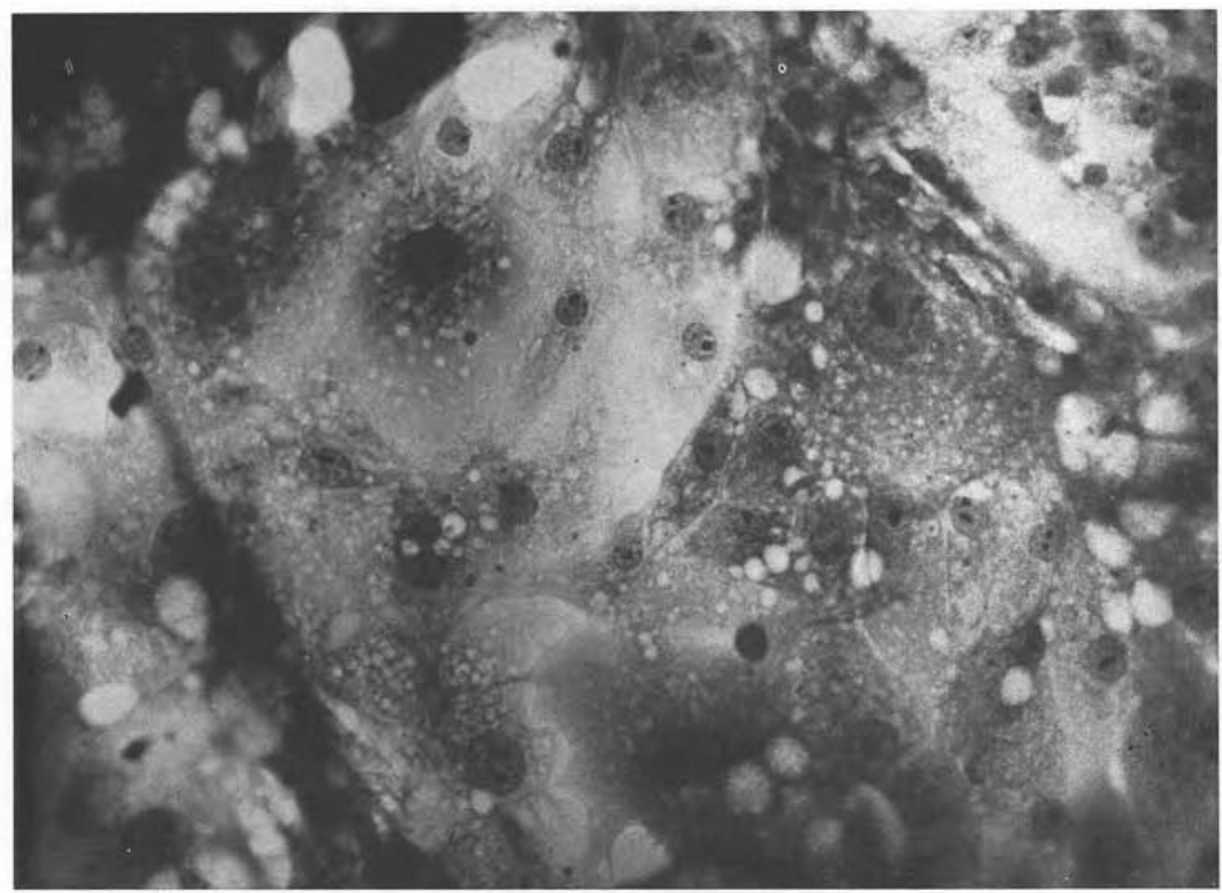

FIg. 5. - Monolayer of Hyalomma dromedarii cells after 10 days cultivation.

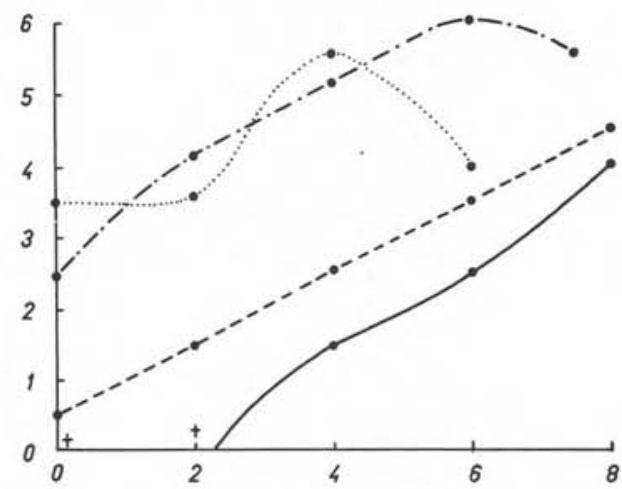

FIG. 6. - Cultivation of tick-borne encephalitis virus in Hyalomma asiaticum cells in vitro

same as in the control-cell free medium. An exception was the LCM virus which multiplied in tick cells.

The growth of Colorado Tick Fever virus was studied in primary tissue cultures of its vector, Dermacentor andersoni, by Yunker and Cory, 1967. After a latent 


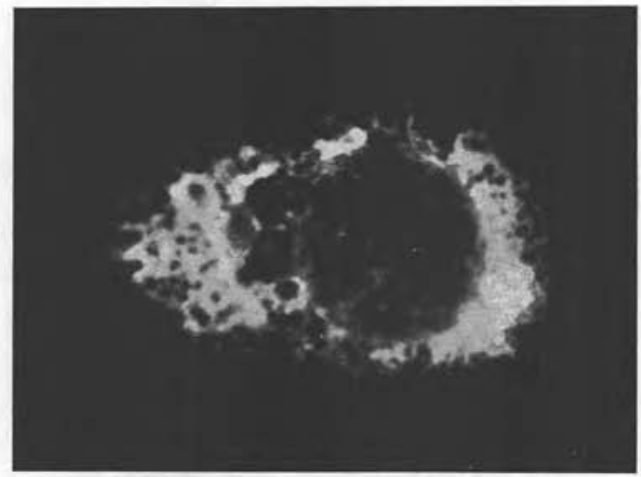

FIG. 7. - Tick-borne encephalitis virus in Hyalommo dromedarii cells in vitro (5 days after the infection) by fluorescent method

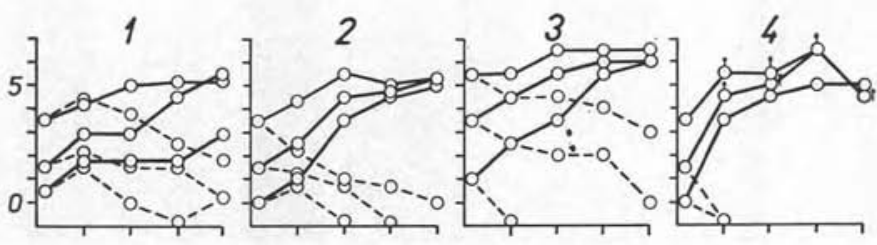

FIG. 8. - Multiplication of WEE (1), EEE (2), Sindbis (3) and Semliki forest (4) viruses in tick tissue cultures - tick tissue cultures; . . . . - controls

Abscissa : days after inoculation; ordinate: virus titers in $\log$ $\mathrm{TCID}_{\mathrm{n} 0} / 0,1 \mathrm{ml}$ values
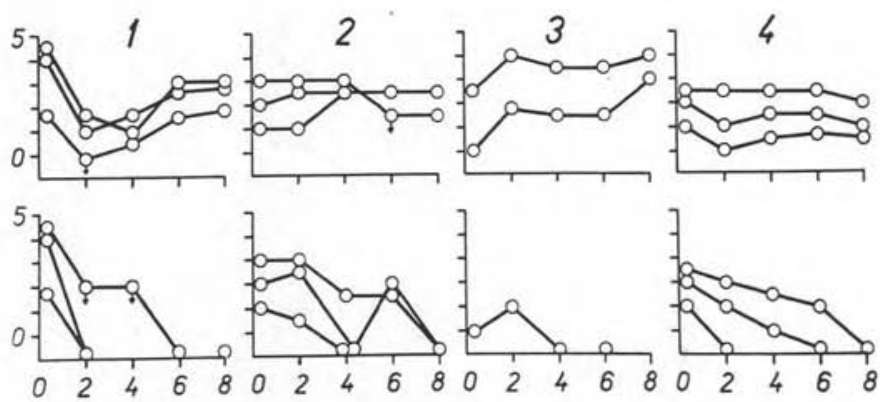

FIG. 9. - Multiplication of Japanese encephalitis (1), St. Louis encephalitis (2), West Nile (3), and yellow fever (4) viruses in tick tissue cultures

top row : tick tissue cultures,

bottom row : controls,

Abscissa: days after inoculation,

Ordinate: virus titers in $\log$ mouse $\mathrm{LD}_{50} / 0,03 \mathrm{ml}$ values. 


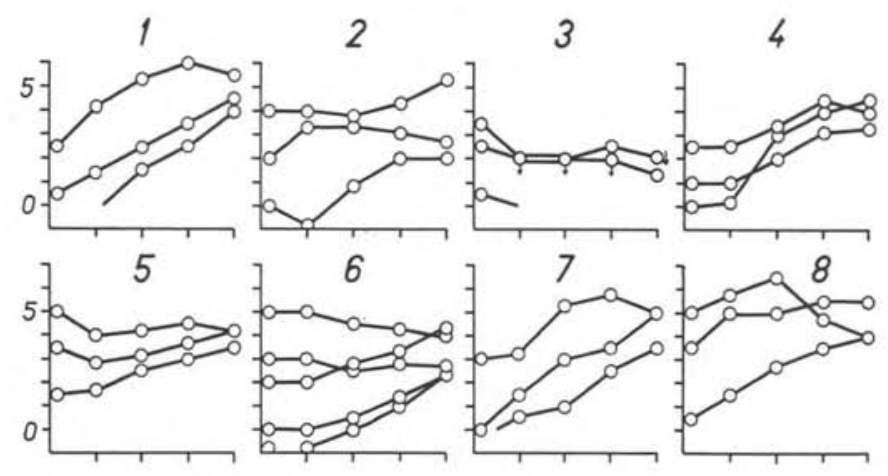

FIG. 10. - Multiplication of European tick-borne encephalitis (1), KFD (2), Langat (3), louping-ill (4), Omsk haemorrhagic fever (5), Powassan (6), Russian spring-summer encephalitis (7), and LCM (8) viruses in tick tissue cultures. For explanation see fig. 9

period of 6-10 days, a $4 \frac{1}{2}$ logarithmic increase of extracellular virus at 4-5 weeks followed. Virus was then isolated successfully in small quantities for as long as 159 days in medium and for 166 days in triturated tissues. It was shown that less than 0,1 of a suckling mouse intracerebral $\mathrm{LD}_{50}$ can be taken up and propagated to higher levels by tick cells in vitro.

Rehacek et al., 1969, described the propagation of Tribec virus in Hyalomma dromedarii tissue cultures. The titers reached $10^{4.5}$ mouse intracerebral $\mathrm{LD}_{55} / 0.1 \mathrm{ml}$ from 4-14 days after infection (Fig. 11). Fluorescent antibody studies revealed the viral antigen in the form of confluent and brightly fluorescing granules in the cytoplasm of infected cells from the second day following inoculation (Fig. 12).

In all these experiments, the tick tissues or cells were not affected by viral infection.

Because tick-borne encephalitis is spread in different countries in Europe, more attention was paid to the relationship of this virus in tick cells in vitro. It was shown that two strains of different origins (one in the 48th mouse brain passage, the second one adapted to HeLa cells) multiplied equally well in the cultures of $D$. marginatus and $H$. dromedarii ticks (Rehacek, 1963). In comparing the susceptibility of small doses of this virus to chick embryo cells and to tick primary cultures of $H$. dromedarii, Rehacek and Kozuch, 1964, found that with inocula of 30 and 3 IFD $_{50}$, the percentage of infected chick embryo cells and tick cell cultures was about equal. With inocula containing 0.3 and $0.03 \mathrm{IFD}_{50}$ of virus, the respective percentage of infected tick cell cultures was 76 and 18 , whereas that of chick embryo cultures only 34 and 3 . Following this, the tick cells were compared in isolation experiments from different materials, i.e. suspensions of rodent brains, blood samples and suspensions of ticks from nature. Altogether 187 samples were tested and from this number 5 strains of the virus were isolated. however. all 5 strains were obtained in tick cells, in chick embryo cells, as well as in mice injected intracerebrally. This indicated that the 


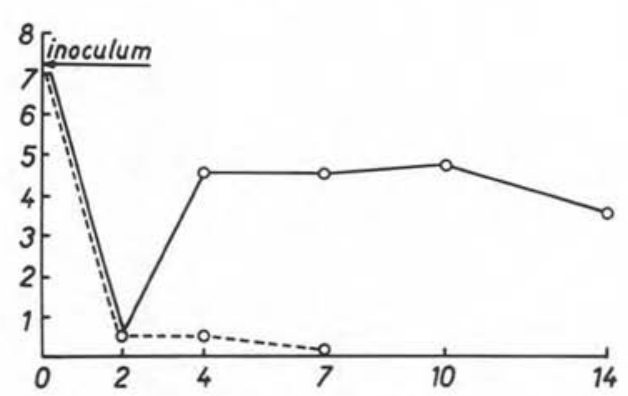

Fig. 11. - Multiplication of Tribec virus in tick tissue cultures

Abscissa: days after inoculation

Ordinate: virus titers in $\log$ mouse $\mathrm{LD}_{\mathrm{50}} /$ $0,01 \mathrm{ml}$ values

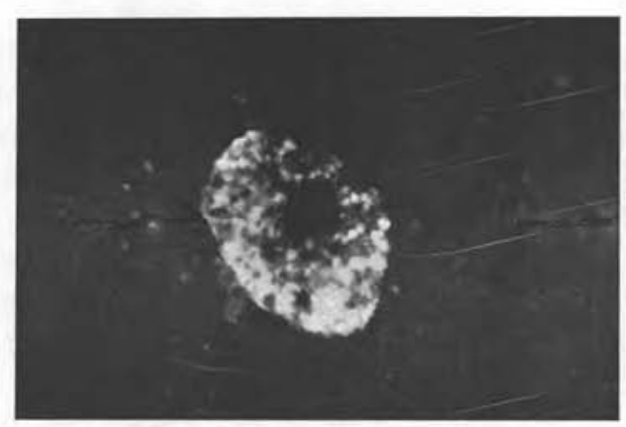

FIG. 12. - Tribec virus in tick cells in vitro ( 7 days after the infection) by fluorescent method

sensitivity of tick cells in vitro to small doses of wild strains of tick-borne encephalitis virus is at least equal to that of chick embryos cells and mice (Rehacek and Kozuch, 1969).

It is well known that ticks are biological vectors of various rickettsial diseases, and it was interesting to determine whether the tick cells in vitro would also be able to propagate the rickettsiae. It was found that Coxiella burneti was propagated in cultures of $H$. dromedarii very well, reaching at 6 days a titer of $10^{6} \mathrm{ID}_{50} / \mathrm{ml}$ in yolk sacs (Rehacek and Brezina, 1964). (Fig. 13), Rickettsia prowazeki, R. mooseri, $R$. conori and $R$. akari also multiplied in tick cells. Simultaneous titrations of rickettsial strains in tick cell cultures and in chick embryos revealed higher sensitivity of tick cell cultures to $R$. conori and $R$. akari. $R$. prowazeki formed chains and threads in the cells (Fig. 14), $R$. mooseri formed segmented chains around the vacuoles, $R$. conori and $R$. akari multiplied in the form of single rods and sometimes in that of diplobacilli. $R$. conori and $R$. akari were found occasionally in the cell nuclei. 


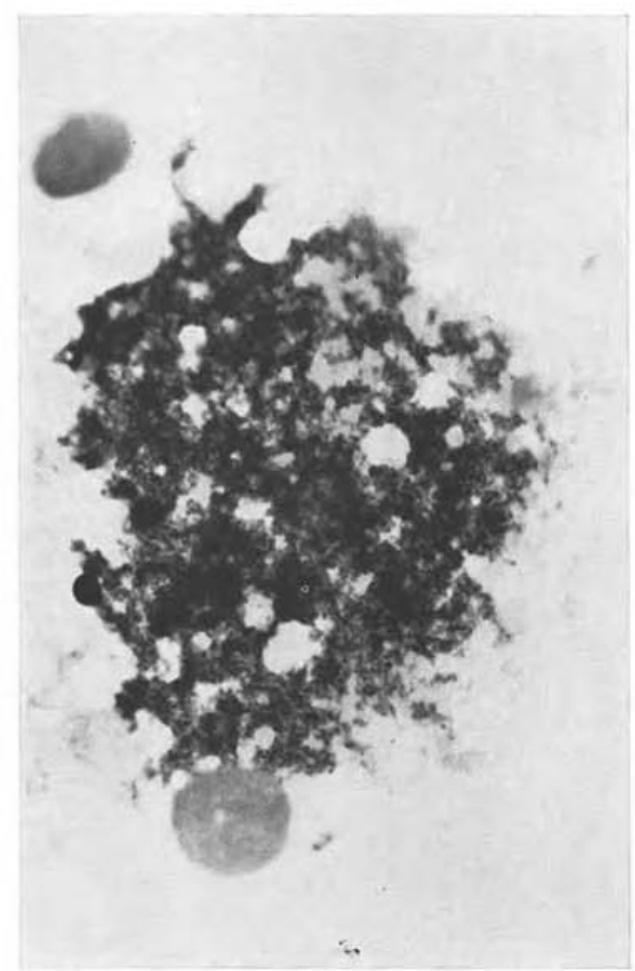

FIG. 13. - Coxiella burneti in tick tissue culture, 4 days after the infection

Lice.

Lice are well known as vectors of several rickettsial diseases, especially epidemic typhus fever and trench fever. Nauck and Weyer, 1941, and Weyer, 1952, used this tissue in vitro for the cultivation of rickettsiae. From the different organs tested, the digestive organs were shown to have the longest survival time (30-40 days).

The explants of different tissues of Pediculus humanus lice were used for the cultivation of rickettsiae by the method of hanging drops of human or rabbit plasma at $31-32^{\circ} \mathrm{C}$. The positive results were obtained only with explants from stomachs of lice infected more than 5 days before the explantation and which had excreted the rickettsiae in their feces. In these cases the propagation of Rickettsia quintana, $R$. prowazeki and $R$. mooseri was observed.

\section{Bugs.}

Experiments on the cultivation of different organs of the bed bug Cimex lectularius in vitro were done by Nauck and Weyer, 1941, in order to find a medium for 


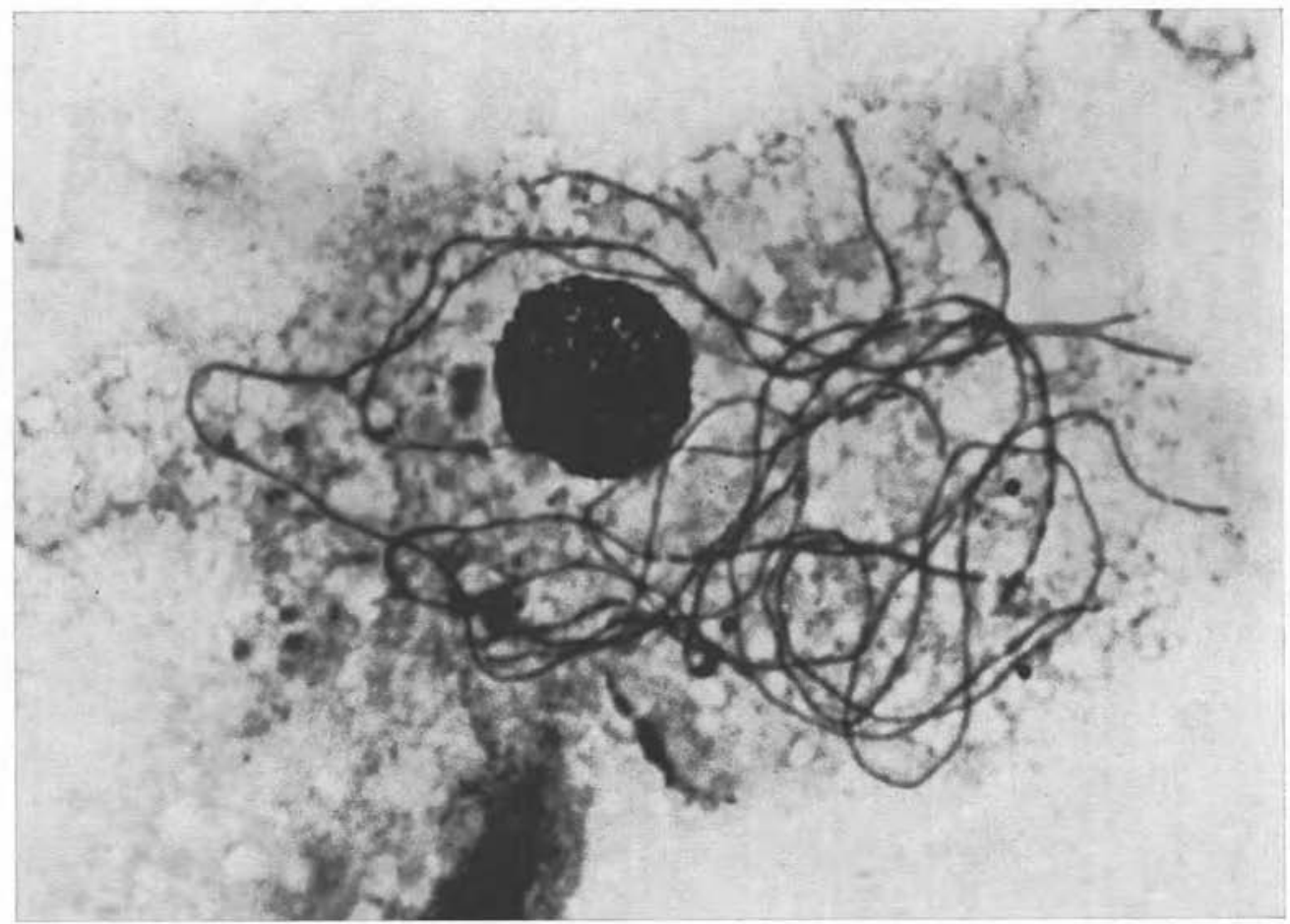

FIG. 14. - Rickettsia prowazcki in tick cells in vitro, 8th day of cultivation

the cultivation of rickettsiae. Unfortunately, tissues survived only about 10 days in vitro. This insect was omitted from further investigation.

A very interesting method for the observation of growth of invertebrate cells and tissues in vitro has been elaborated by Lüscher, 1947, 1948. The method is based on the fact that epithelial cells after injury will grow along any surface and that if a tissue injury is covered with glass, the cells will spread on the surface of the glass. This has been accomplished with the hind leg of the fifth stage nymph Rhodnius prolixus which was amputated in the distal part of the tibia and a glass tube introduced into the opening of tibia. By the use of this method many cell divisions in the migrating haemocytes in the first day were seen together with the epithelial cells which formed a sparse network of cells interconnected by protoplasmic processes.

Later Vago and Flandre, 1963, observed the mitoses in fibroblast-like cells which migrated out from the explants of ovaries and malpighian tubes of Triatoma infestans cultured in plasma clots and a special medium.

The promising primary cultures of Heteroptera which might be used for the cultivation of microorganisms were derived by Varma and Pudney, 1967. The embryonic cells of the bug Triatoma maculata were used. After setting up the cultures, the outgrowth of fibroblast-like cells occurred at the periphery of the cell clumps. The 
cells then joined together to form a loose network. The epithelial cells were included in the networks, and most cells remained healthy up to about 40 days when the degeneration slowly occurred.

\section{Flies.}

The blood-sucking fly, Glossina palpalis, species was employed in experiments for cultivation in vitro (Trager, 1959). Preimaginal tissues obtained from pupae and the different organs of the adult were used. Various modifications of media based mostly on Wyatt, 1956 and Grace, 1958, were successfully used. The outgrowth of cells was observed to occur from the brain, optic lobe, proventriculus and hind gut. The viability of organ explants was demonstrated by their contractibility. Imaginal buds were found to be the best source for the cells of different types. The formation of confluent sheets and networks of cells with mitoses occurred, and some of the cell cultures were found in excellent condition up to 35-43 days.

\section{Fleas.}

The use of the cells and tissues of fleas would be helpful in the explanation of the relation between the vector cells and the agents transmitted by them. Nauck and Weyer, 1941, tried to develop a culture of viscera of the adult Ctenophthalmus segnis fleas but it was not successful.

\section{Mosquitoes.}

The culturing of mosquitoes has been a prime concern of most investigators of arthropod cell cultures.

Explant cultures have been derived from different organs of various mosquito stages. These cultures survived for limited periods and sometimes demonstrated limited migration of epithelial or fibroblast-like cells.

The first notable experiments of this kind were done by Trager, 1938, who used the explants of larvae, pupae and adults of Aedes aegypti for the propagation of the WEE virus. The best results were obtained with the tissues of the midgut of fullgrown larvae and ovaries of newly emerged females. The larvae tissue survived at least 30 days, the ovary tissue up to 47 days. The various mosquitoes tissues supported virus propagation. Best results were obtained with subcultures which were started in larval thoracic tissue, then passed in pupal head tissues, passed again in larval thoracic tissues and finally in pupal head tissues. After 28 days, including 4 passages at 7 days intervals, the titer was $10^{5}$ times higher than that of the original suspension.

In further experiments, salivary glands, thorax muscles and gut of Anopheles maculipennis and Stegomyia fasciata were cultivated in chick plasma containing larval mosquito extract. Migration of cells was observed with little cell multiplication (Gavrilov and Cowez, 1941).

Ragab, 1948, 1949, derived a method for the cultivation of isolated mosquito gut in which a continuous flow of nutrient medium was passed over the isolated 
gut, however no marked increase in the survival time of the explanted organs was obtained. A saline solution prepared by Bradford and Ramsay, 1949, based on the analysis for sodium and potassium of the midgut and malpighian tubules of Aedes aegypti, was found suitable for the survival of mosquito organs in vitro.

In 1956, Beckel did experiments on mosquito egg development in vitro. The extirpated ovaries of Aedes hexodontus, Aedes aegypti and A. communis were maintained in vitro; the muscle tissue of $A$. hexodontus and $A$. communis ovaries showed contraction for as long as 7 days, the $A$. aegypti tissue demonstrated contraction for as long as 60 days. In both cases there was no development of eggs.

Various tissues of the pupae, larvae and eggs of $A$. aegypti mosquitoes were used in vitro for the cultivation of EEE virus by Haines, 1958. Embryonic tissue was maintained in medium TC 199 for 5-21 days, pupal ovary tissues up to 10 days and fourth instar larval midgut tissues up to 23 days. The latter was chosen for the experiments on the cultivation of EEE virus but only the short time virus survival was found.

The mosquito stomachs, surviving in vitro, were of interest and convenient substrates for the study on the development of Plasmodium oocysts. Ball, 1947, 1948, used for this purpose the stomachs of Culex tarsalis whose hindgut showed contractibility for as long as 7 days. Unsatisfied with the results on the stomach cultivation, in relation to previous results on the amino acids analysis of the culicid tissues, Ball, 1954, modified his medium. Although contraction was observed for as long as 5 weeks, the epithelial and muscle cells of the midgut almost degenerated and were unrecognizable by this time.

More recently, Gubler, 1968, cultured organs of the female Culex pipiens molestus. In a simple medium consisting of salts, sugars, few organic acids, lactalbumin hydrolysate and fetal bovine serum, explanted ovaries were maintained without loss of shape, size, and contraction for over 80 days. The gut was maintained for 47 days. Explants of midguts of mosquitoes (A. aegypti) infected with Plasmodium gallinaceum oocysts were cultivated by Schneider, 1968. She found the slightly modified medium of Grace, 1958, most suitable.

Maitland-type tissue culture system from minced germ-free larvae and pupae of the mosquitoes $A$. aegypti and A. triseriatus have been developed by Johnson, 1967, 1969. Minced tissues maintained in suspensions were cultivated in Clements medium. Johnson used these cultures for the cultivation of VEE and EEE viruses. Both of the viruses multiplied in cultures very well and Johnson described in detail several factors concerning this propagation. He found the adsorbtion rate appeared to be nearly constant at temperatures from $4-30^{\circ} \mathrm{C}$, but at $37^{\circ} \mathrm{C}$ the values dropped off sharply. The agitation of the cultures during the virus adsorption process showed no significant effect on the amount of virus adsorbed but it was an important factor in increasing the yield of virus. Maximum yield of viruses were found also to be dependent on the amount of virus present in the adsorption mixtures and incubation temperatures. The amount of mosquito tissue seeded per $\mathrm{ml}$ of culture fluid showed little effect over the range from 20 to 200 larvae per $\mathrm{ml}$. The titer of the Trinidad strain of VEE virus was essentially constant and a $\mathrm{pH}$ range of 7-8 gave a slightly depressed 
growth rate. It was found the supernatant fluid of mosquito cultures contained less virus about 0.5 logarithmic units than the cells. Similar results as with A. aegypti have been reached with Aedes triseriatus and, in general, with EEE virus. The virulent strain Trinidad of VEE was serially passed ten times in A. aegypti larval tissue cultures and five times in pupal tissue cultures showing only a slight increase in the peak titers attained with virus in both culture types. No change in the mouse virulence or the plaque characteristics of the virus was observed. The less virulent 9 th strain of VEE virus showed no changes in growth rate or peak titers after five serial passages in the same type of cultures.

\section{Mosquito primary culture.}

Primary mosquito cultures have been established from all developmental stages. Three categories of insect cell growth are known (Larsen, 1967) and all of them were found in mosquito tissue cultures (Singh, 1967 ; Bhat and Singh, 1969). This growth can be characterized by the formation of cell sheet, by establishment of large hollow spherical vesicles and by means of elongate hollow tubes.

The first experiments on the cultivation of the mosquito primary cultures were done by Peleg and Trager, 1963, who used the imaginal discs of fourth instar larvae of A. aegypti. Using Trager's medium (Trager, 1959) with calf serum replacing the sheep serum, they noticed the establishment of a single layer within a boundary of its limiting membrane followed by cell migration through the membrane. The cells were maintained as long as 40 days. Enriching of medium with $10 \%$ chick embryo extract had considerable beneficial effect on cell growth. These types of cultures supported the multiplication of West Nile virus resulting in an increase of 2 logarithmic units of views during a period of 25 days. The authors also observed the propagation of virus in mosquito tissues during four serial passages. No cytopathic effect was noted in the infected cultures.

Later Peleg, 1965, markedly improved the growth of mosquito cells in vitro by enriching Trager's medium with $20 \%$ calf serum and $1 \%$ chick embryo extract. In these experiments he used the cells prepared from whole larvae. Under this condition 5 months growth of cells was noted. Later, Peleg, 1966, continued the improvement of primary mosquito cultures using the cells from wholly or partially disintegrated $A$. aegypti embryos. The eggs, after careful surface sterilization for 5 minutes in $0.05 \%$ $\mathrm{HgCl}_{2}$ in $70 \%$ ethyl alcohol and successive washing in distilled water, were pressed through steel grid and collected. They were then suspended in the modified Trager's medium, where in addition to an altered salt composition, yeast extract was replaced with the vitamins of Eagle's medium (Eagle, 1955). In this medium with $2 \%$ chick embryo extract added, whole microscopic fields were seen to be covered with new cells and many mitotic figures could be demonstrated on the 5th and 6th days.

Kitamura, 1964, successfully cultivated cells derived from ovarian tissues of Culex pipiens var. molestus. A simple and convenient medium was used. $\mathrm{NaCl} 0.65 \mathrm{~g}$, $\mathrm{KCl} 0.05 \mathrm{~g}, \mathrm{CaCl}_{2} 0.02 \mathrm{~g}, \mathrm{NaHCO}_{3} 0.01 \mathrm{~g}$, glucose $0.8 \mathrm{~g}$, lactalbumin hydrolysate $1.0 \mathrm{~g}$, distilled water $100 \mathrm{ml}$, chicken plasma $10 \mathrm{ml}$, antibiotics. Dividing cells were 
seen for more than 3 weeks when the medium was changed every 4 th day. Kitamura, 1965 , further improved the medium composition with mostly an enrichment with $20 \%$ of synthetic mixture No. 199. The ovaries were found to be contracting and the outgrowth of cells continued for more than three months when the culture medium was replaced every sixth day. Kitamura, 1966, further continued the improvement of the cultivation technique in an effort to investigate the origin of growing cells and to subculture these cells. Different cell types were found to grow from the ovaries of three species of mosquitoes, Culex molestus, Aedes albopictus and Aedes aegypti, for long time periods, often forming a cell sheet. Decrease of cell yield was observed up to the 8 th subculture.

Gubler, 1968, described a method for the preparation of primary mosquito cultures from adult Culex pipiens var. molestus ovaries and guts, when the peritrophic membrane of the latter was extracted before the seeding of the organ explants. Ovarian and midgut tissues showed good migration of epithelial cells followed by the formation of cell sheets for about 3 weeks. The principal cells of the sheet were epithelial in appearance. Fibroblast-like cells were observed in young cultures, giant cells and syncytia occurred in older cultures. Subculturing has been unsuccessful.

A sufficient amount of primary cultures has been used for the cultivation of different viruses. Peleg, $1968 a$, cultivated EEE, Semliki Forest (SF) and West Nile viruses in primary tissue cultures of Aedes aegypti embryos. All these viruses were multiplying very well. Differences in the growth pattern were found in the release of virus from cells. The release of SF virus began about 8 hours, West Nile virus after 36-48 hours after infection. SF virus increased more rapidly reaching a peak titer in 2 days, while West Nile increased significantly slower reaching a peak titer 8-10 days after infection. On the other hand SF virus declined the fastest with two pronounced falls in titer in comparison with West Nile virus in which the decline in titer was slower and longer. EEE virus occupied an intermediate position between these viruses tested. The cultures infected with West Nile virus yielded positive results with the direct staining method of the immunofluorescence technique. Slight morphologic changes have been found in a few cultures infected with EEE and SF viruses, nevertheless, their attribution to virus infection is questionable.

Japanese Encephalitis (JE) virus was cultivated in primary cultures of ovaries of Culex molestus by Fujita et al., 1968. An increase of titer at the 4th day of incubation reaching a maximum $\left(10^{4.5}\right.$ per $0.02 \mathrm{ml}$ in mouse i.c. $\left.\mathrm{LD}_{50}\right)$ at the 7 th day was shown. The virus was found up to 65 days in the medium with some variation in titer. No apparent cytopathic effect was seen in the infected cells. The positive reactions of immunofluorescence staining were found 1-3 hours after the inoculation of virus. At about 36 hours they appeared again, increasing in intensity with lapse of time, when caused by the propagated virus. The fluorescence was noted first in the juxtanuclear area and then spread out over the whole cytoplasm sometimes as a number of tiny brilliant spots or condensed masses appearing mainly in the peripheral parts of the cells. The virus was serially transmitted through mosquito cultures, the original virus inoculum was diluted $10^{27}$ times during 164 days and it retained its 
mouse infectivity throughout these cultures, holding mouse $\operatorname{LD}_{\overline{5} 0}$ titers of about $10^{3}$ to $10^{4}$ per $0.02 \mathrm{ml}$.

Primary cell cultures from the embryos of Anopheles stephensi mosquitoes were established by Singh and Bhat, 1969. The explanted cells and fragments multiplied very well and at about the tenth day most of the vessel surface was covered with them. Four different types of cells were observed, the predominant cells being muscle cells, followed by fibroblast-like cells, rounded cells and epithelial like cells. Also a large number of vesicles were observed in cultures. Amitotic divisions were seen in muscle cells. Subculturing of cells was unsuccessful, however, the cultures were maintained for more than five months in good condition.

Mosquito stable cell lines.

Stable lines of arthropod cells in vitro were established first by Grace, 1962, from ovarian tissue of the Saturniid Antheraea eucalypti. The same author (Grace, 1966) derived the first stable cell line from blood-sucking insect $A$. aegypti larval tissues. This cell line is maintained in Grace's medium (Grace, 1966) which is now produced commercially. Suitor et al., 1966, adapted this line to medium containing Grace's medium plus $10 \%$ fetal bovine serum with $0.5 \%$ Philosamia cynthia pryeri haelmolymph, and succeeded in cloning the spindle-shaped cells. Mosquito cells were grown in suspension in a special modified medium, designated No. 35 (Nagle, 1969) which was improved by increasing the level of choline in the medium, with an optimal concentration of $50 \mathrm{mg} / \mathrm{l}$. Grace's cell line was found to be intolerant to Fungizone, a commercial preparation of the polyene amphotericin B (Stanley and Vaughn, 1967). The mosquito cells exhibited cytopathology in $1 \mu \mathrm{g} / \mathrm{ml}$ and no mosquito cultures tolerated $3 \mu \mathrm{g} / \mathrm{ml}$.

The adaptation of Grace's line to haemolymph-free media (Nagle et al., 1967 : Sweet and Dupree, 1968, unpublished results; Suitor, 1968, unpublished results ; and Nagle, 1969) enabled the wide use of cells for the cultivation of different microorganisms. Plasmodium gallinaceum oocysts (Schneider, 1967 and 1968), microfilariae Macacanema formosana (Wood and Suitor, 1966) and viruses were cultivated in a specially modified medium.

The first set of experiments concerning the determination on sensitivity of Grace's mosquito cells to different arboviruses were done by Rehacek, $1968 a$. The cells, cultivated at $28^{\circ} \mathrm{C}$, supported the propagation of JE, Murray Valley Encephalitis (MVE), Kunjin and West Nile virus (Fig. 15-18) but not Sindbis, SF, Bebaru, Edge Hill and Kokoberra viruses. The viruses which multiplied showed no greater growth than 1 logarithmic unit per day, but they multiplied for a long time period. Only a slightly unclear cytopathic effect was found in cells infected with JE virus. The Asibi strain of yellow fever virus could be propagated in this cell line. The virus exhibited a 2 log. increase in titer within 24 hours, followed by lowered titers on subsequent days (Conserve and Nagle, 1967). Filshie and Rehacek, 1968, described the replication and morphology of MVE and JE viruses in mosquito cells by means of electron microscopy. The viral particles were seen in initially infected cells and in persistently infected cells. MVE virus particles were first observed in acutely infected cells 6 days 


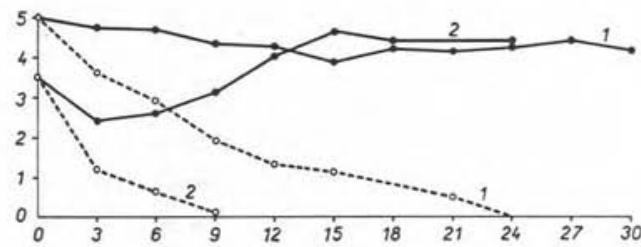

FIG. 15. - Growth curves of Murray Valley Encephalitis virus

Abscissa: days P.I. ; ordinate: virus titer in $\log$ PFU/ $\mathrm{ml}$ values

Mosquito cell cultures: 1-all medium changed. $2-2 / 3$ of medium changed

Controls : $1-1 / 3$ of medium changed; $2-2 / 3$ of medium changed

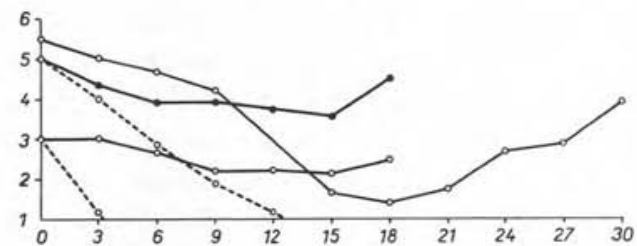

FIG. 16. - Growth curves of Japanese encephalitis virus

Abscissa and ordinate as in fig. 15

Mosquito cell cultures (all medium changed) ..... Controls (1/3 of medium changed)

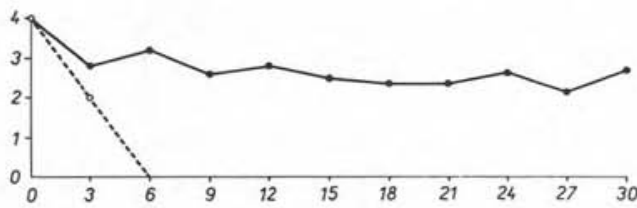

FIG. 17. - Growth curves of Kunjin virus Abscissa and ordinate as in fig. 15

Mosquito cell culture (all medium changed) ...... Control (2/3 of medium changed)

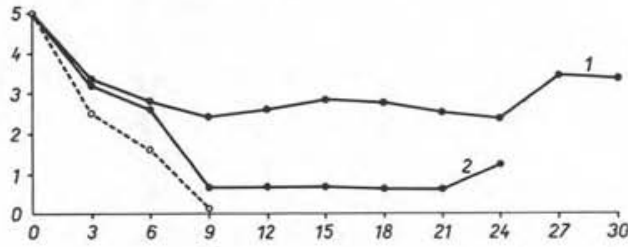

FIG. 18, - Growth curves of West Nile virus Mosquito cell cultures; 1-all medium changed; $2-2 / 3$ of medium changed Control ( $2 / 3$ of medium changed) 
after inoculation and in persistently infected cultures in the 5th passage and the 6th day after seeding. In infected cells, mature particles are always contained within vacuoles or elements of the endoplasmic reticulum, never free in the cytoplasm. From the 6th day, large vacuoles frequently contained single particles and crystalline groups of particles in addition to other debris apparently ingested from the culture medium by phagocytosis. On the 9 th day, about $5 \%$ of cells contained virus particles.

Rehacek, $1968 b$, described the persistent infection of MVE and JE viruses in Grace's cells. After almost 21 weekly passages for 210 days, the different qualitative and quantitative relations and the properties of viruses and infected cells were followed. A slow and permanent loss of virus content was found with an increase in the number of passages; the higher amount of virus particles always being present in the cells at 1-2 logs higher than in the medium. There was no difference in the growth rates of cells infected with $\mathrm{MVE}$ virus and uninfected cells, but there was a significant decrease of cells infected with JE virus when $5.2 \times 10^{5}$ cells $/ \mathrm{ml}$ were used for seeding of the passage. The infected cells of 15 th passage, cultivated in the presence of specefic antibodies, lowered gradually their virus amount and no virus was detected in the cells infected with MEV virus after the 4 th and in JE virus infected cells after the 3rd subsequent passage, when the medium was changed twice during each weekly passage. The infected cells could be superinfected with $10^{4} \mathrm{PFU} / \mathrm{ml}$ of Kunjin virus at their 13th and 18th passages. During the course of these experiments the size and appearance of plaques was studied, but no significant change was observed with either MVE or with JE viruses. In the 4 th, 10 th and 20th passage the virus yields were titrated by the inoculation of infant mice intracerebrally and subcutaneously and by the plaque method. The results showed almost no change in pathogenicity for mice for both the viruses tested at the 4 th and 10 th passage and a decrease of pathogenicity at the 20th passage when inoculated subcutaneously.

Singh, 1967, succeeded in establishing further cell lines-three lines of freshly hatched larvae of Aedes albopictus and two of Aedes aegypti mosquitoes. The culture medium of Mitsuhashi and Maramorosch, 1964, was used without haemolymph. The cells were maintained in the medium with $10 \%$ fetal bovine serum. Mainly three morphological types of cells were seen in A. albopictus cultures. The predominant type was round and 6-20 $\mu$ in diameter. The second type was spindle-shaped, 7-10 $\mu$ wide and 15-90 $\mu$ long. The third type of cell was binucleated, round and 37-53 $\mu$ in diameter. On the other hand, the growth pattern of the $A$. aegypti cultures was different in that they developed from the cells of hollow vesicles. These cells consisted mainly of an epithelial type of cell and even after many subcultures still had a tendency to form hollow vesicles and occassionally tube-like structures. Both cell lines have been used extensively for the cultivation of different viruses.

Singh and Paul, $1968 a$, used the cell lines from the 22nd to the 29th passage for the cultivation of Chikungunya, Sindbis, Kyasanur Forest Disease (KFD), JE, dengue 1 , dengue 2 , dengue 3 , dengue 4 viruses. Chikungunya, Sindbis, JE and West Nile viruses, all mosquito-borne viruses, grew well in $A$. albopictus cell cultures. 
Approximately a $10^{4}-10^{8}$ fold increase over the original inoculum was observed. All the dengue types of viruses, which are also mosquito-borne viruses, multiplied in the same cultures but the maximum titers reached did not exceed $10^{2.0}$ to $10^{3.0} \mathrm{LD}_{50}$. On the other hand, A. aegypti cell line supported the multiplication of only Chikungunya and West Nile viruses. Neither of the cell lines supported the growth of KFD virus, which is a tick-borne virus. Cytopathic effect was observed with JE, West Nile, dengue 1 , dengue 2 and dengue 4 viruses in only $A$. albopictus cells. Paul et al., 1969, described in detail, the cytopathic effect in cells infected with West Nile, JE and dengue 2 viruses. In the case of the West Nile virus infection, mostly a slight thinning out of cell population with fewer mitotic figures was seen on the second day in comparison with uninfected cells. No cytological changes were seen except the withdrawal of ectoplasm by a small proportion of small cells as evidenced by the stretching of intercellular bridges across and increased pericellular space. Some of the small cells were rounded up with their cytoplasm showing increased basophilia in the vicinity of the nucleus. On the fourth day a gross reduction was noted in the total cell population. A very large number of small cells showed a withdrawal of ectoplasm and ectoplasmic bridges, followed by the formation of syncytial masses and a large number of multinucleate cells. Active phagocytosis of small cells was seen in the cultures. From the fifth to tenth day basically the same changes were noted except that they were much advanced, including disintegration of cell sheets into an amorphous acellular debris, cytolysis with phagocytosis of the small cells. On the twelfth to thirtieth day post inoculation the cellular debris disappeared through phagocytosis or from detachment from the glass walls and the cultures were composed of an increased population of cytologically healthy looking small cells and multinucleate cells of various shapes and sizes with variable numbers of nuclei. No intracellular or cytoplasmic inclusions were seen in any of the infected cultures. The cytopathic changes with JE and dengue 2 viruses were essentially similar,

Singh and Paul, $1968 b$ continued in the cultivation of several viruses in both mosquito cell lines. Of those cultivated were Sathuperi, Batai (Chittoor), Ganjam, African horse sickness (AHS), Chandipura, Dhori, Kaisodi, KFD, EMC, polio I., coxsackie B 5 and mouse-hepato-encephalitis (HE) viruses. Sathuperi, Batai, Ganjam, AHS and Chandipura viruses multiplied in A. albopictus cells as compared with $A$. aegypti cells where only Chandipura virus multiplied. In this cell line AHS virus was not cultivated. No cytopathic effect was seen in the cells of both cell lines infected with any of the above mentioned viruses.

As with Grace's $A$. aegypti cells also with $A$. albopictus cells the carrier state of viruses was described (Banerjee and Singh, 1968). These viruses included JE, West Nile and Chikungunya viruses. The carrier culture infected with JE virus were at the time of the publication in the 13th passage, West Nile virus in 8th passage and Chikungunya in the 7 th passage. The JE virus titers in different passages ranged from $10^{6.0}$ to $10^{8.0} \mathrm{LD}_{50} / \mathrm{ml}$ in adult mice, the virus titers of the West Nile from $10^{5.1}-10^{6.0} \mathrm{LD}_{50} / \mathrm{ml}$ in adult mice and the virus produced by the Chikungunya infected cultures was at a substantially lower level than both those mentioned. 
Suitor and Paul, 1969, confirmed the cytopathic effect caused by dengue 2 virus cultivation in A. albopictus cells and described the cell syncytia formation when the infected cells were cultivated in plastic containers. These syncytia often have wavy or striated patterns containing large numbers of nuclei. The monolayer often becomes one large syncytial mass by the eighth to tenth day. Comparative endpoints of type 2 dengue virus pool on PS/Y 15 (porcine kidney) cells and in suckling mice showed that the formation of syncytia in A. albopictus cells is more sensitive than plaque formation or tests in suckling mice.

Another virus successfully cultivated in A. albopictus cell lines was Colorado Tick Fever (CTF) virus which multiplied with titers of 2.2-2.6 logs during the 3rd-4th weeks following inoculation without causing cytopathic effects (Yunker and Cory, 1969). This was the first report of the multiplication of a virus transmitted in nature by ticks in insect cells in vitro.

Paul and Singh, 1969, compared the sensitivity of mosquito cell lines to infection with arboviruses with that in infant mice and the VERO cell line. Six viruses (Chikungunya, West Nile, JE, dengue 2, Batai and Chandipura) were used in these experiments. It was shown that Aedes aegypti cells supported the growth of only Chikungunya, West Nile and Chandipura viruses and are much less sensitive to infection with arboviruses than $A$. albopictus cell line which is equally or slightly more sensitive to Chikungunya, West Nile and JE viruses, slightly less sensitive to Batai and Chandipura viruses as compared to infant mice and VERO cells, however, it is 100 times more sensitive than VERO and 40 times more sensitive than infant mice to infection with dengue 2 virus.

Aedes albopictus cell line has been used also by Yunker and Cory, 1968, for testing of a few arboviruses. The authors found that St. Louis Encephalitis (SLE), JE and West Nile viruses propagate to significant levels above the amounts inoculated, but Powassan and Langat which occur in the same arbovirus group but are tick-borne members, do not propagate.

Comprehensive studies on the sensitivity of Singh's cell lines to infection with arboviruses were done by Buckley, 1969 to determine whether the A. albopictus and $A$. aegypti cell lines could efficiently serve as in vitro assay systems for arboviruses. Twenty three different arboviruses were screened for their ability to multiply in mosquito cells at $30^{\circ} \mathrm{C}$ and $35^{\circ} \mathrm{C}$. Buckley found cytopathic effects only in A. albopictus cells infected with West Nile virus. Both Aedes cell lines demonstrated infections with Chikungunya, EEE, SF, VEE, SLE, West Nile, yellow fever and vesicular stomatitis viruses. CTF multiplied only in A. albopictus cells but not in A. aegypti cells while the remaining 13 viruses (Cowbone Ridge, Modoc, Sicilian and Naples sandfly fever virus, Langat, Farallon, Silverwater, Chenuda, Johnston Atoll, Qualyub, Bandia, C 558 and URB-TMA 1381) failed to multiply in either mosquito cell line.

Sweet and Dupree, 1968, derived cell lines from female Culiseta inornata and pupal tissues of Aedes vexans. The cells of both lines grow as free floating cells rather than as monolayers. C. inornata lines were at the beginning of September, 1969 in 
the 62nd passage and $A$. vexans at the 54th passage (Sweet, personal communication). Both cell lines resemble morphologically, by cultural characteristics and by immunological criteria the Antheraea and A. aegypti lines derived by Grace. Both cell lines have been used for the cultivation of SLE, EEE, Cache Valley and California viruses. Using a low multiplicity input and not changing the media, and holding for a period of 14 days, no significant viral multiplication above the input level occurred. SLE virus demonstrated a low level multiplication, or represented residual virus that was more stable in the presence of the mosquito cells (Sweet et al., 1968). In a further study, Sweet and unthank, 1969, observed the multiplication at low levels of SLE and JE viruses over a 6 weeks period in the cells of $C$. inornata, A. vexans and Grace's A. aegypti cells.

Further cell lines have been derived from embryonic tissues of Aedes aegypti by Peleg, $1968 b$ and successfully used in 8-22 cell passages for the cultivation of EEE, SF and West Nile viruses. All of these viruses multiplied, culminating in a 100 to 10,000 -fold increase in titer. Peak titers were attained by SF and EEE viruses in 2 or 3 days and West Nile virus increased at 6-7 days following infection. SF virus was isolated at 210 days, EEE at 70 and West Nile at 145 days from the cultures following infection. No cytopathic changes or differences in the lifespan of infected and normal cultures which could be due to the propagation of viruses tested were observed. The same author, Peleg, $1968 c$, studied whether the mosquito cells in vitro could be infected with viral RNA. The results showed that the embryo cells in 24-35 passages inoculated with RNA of SF and West Nile arboviruses yielded virus progenies but those of EMC and polio viruses did not. Peleg explained that differences in the growth behavior of RNA could be related to intracellular factors.

Three further cell lines have been established from the first instar larvae of Anopheles stephensi by Schneider, 1969. Modified Grace's medium was used. In contrast to other insect lines, the cells of these lines are diploid having predominantly 6 chromosomes. The results of these cells used for the cultivation of any pathogen have been not as yet published.

The recently described cell lines were established from Aedes aegypti larvae by Varma and Pudney, $1969 \mathrm{~b}$, who derived three different cell lines, and the growth of arboviruses in these cell lines is being studied.

\section{Conclusions.}

Tissue cultures of lice and fleas which might be used for the cultivation of different microorganisms are not yet available and therefore, these media are as yet of no concern for arbovirologists.

The development of cultures from bugs, flies and ticks is now in the stage of reasonable primary cultures, nevertheless, their wider use for microbial studies is 
limited by the few cultures available and difficult preparation. Despite these troubles, tick tissue cultures have been used successfully for the cultivation of different viruses and rickettsiae and the results obtained can serve for possible criteria in diagnosis of various virus groups. The results indicate several viruses and rickettsiae have a high affinity to tick cells; for example tick-borne encephalitis, Colorado Tick Fever virus and Coxiella burneti, Rickettsia conori and R. akari. These cells could be used in the isolating of these agents from nature.

The establishment of many cell lines from mosquitoes, mostly of the Aedes species, has allowed many workers to use them in virus studies. Most of the studies are concerned with their sensitivity to arboviruses multiplication and classification of virus groups. The very high sensitivity of these cells to several arboviruses also offers a convenient medium for their isolation nature. Cells for the multiplication of various arboviruses might be used in routine arbovirus work in laboratories investigating various properties and morphology of these viruses.

The first step in arbovirus and rickettsiae studies in arthropod cells in vitro has been the establishment and determination of their sensitivity to pathogens. The second step now follows, i.e. the comparison of the sensitivity to vertebrate cells in vivo and in vitro and the application of results.

The question is open on the use of arthropod cells in vitro for the propagation of agents which might be useful in biological control of arthropods. Such studies have not yet been accomplished. Studies by Filshie et al., 1967, on the latent infection of an unknown virus in mosquito cells emerging arbovirus infection (fig. 19) may lead to solving this problem, but no data is yet available.

It would be difficult to interpret the results of the propagation of pathogens in arthropod cells in vitro for conclusions on their biology in arthropods. Such results, as for example with the Japanese Encephalitis and St. Louis Encephalitis viruses which are not ordinarily transmitted by Aedes vexans, A. aegypti or Culiseta inornata in nature have been shown to multiply in the cells of these arthropods in vitro. On the other hand, Cache Valley and California encephalitis viruses have been isolated from $C$. inornata mosquito and do not multiply in the cell lines of this species (Sweet and Unthank, 1969) support this premise.

Despite this slightly pessimistic conclusion, we suggest that tissue cultures of arthropods are a convenient tool, especially for arbovirologists. Their wide application for studies of the arthropod cell and virus relationships will follow. 


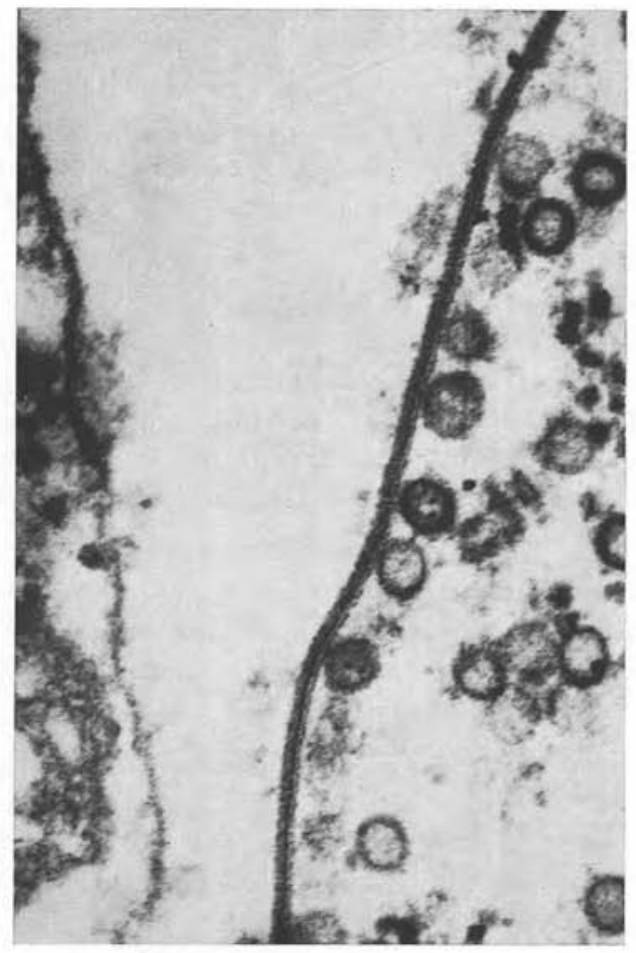

Fig. 19. - Structurally identical particles in the cytoplasm of Aedes mosquito cell, 9 days after infection with Murray Valley Encephalitis virus. Most particles appear \& hollow \& but a few have centrally disposed dense granules. Particles are interspersed with ribosomes, R. $120000 \times$

Table I. Survey on mosquito cell lines.

\begin{tabular}{|c|c|c|}
\hline SPECIES & Stage & AUTHOR \\
\hline $\begin{array}{l}\text { Aedes aegypti } \ldots . . . . \\
\text { Aedes albopictus } \ldots \ldots \\
\text { Aedes aegypti } \ldots \ldots \ldots \\
\text { Aedes aegypti } \ldots \ldots \ldots \\
\text { Culiseta inornata } \ldots \ldots \\
\text { Aedes vexans } \ldots \ldots \ldots \\
\text { Anopheles stephensi .... } \\
\text { Aedes aegypti ........ }\end{array}$ & $\begin{array}{l}\text { larval tissues } \\
\text { larval tissues } \\
\text { larval tissues } \\
\text { embryonic tissues } \\
\text { adult female tissues } \\
\text { pupal tissues } \\
\text { larval tissues } \\
\text { larval tissues }\end{array}$ & $\begin{array}{l}\text { Grace, } 1966 \\
\text { Singh, } 1967 \\
\text { Singh, } 1967 \\
\text { Peleg, } 1968 b \\
\text { Sweet and Dupree, } 1968 \\
\text { Sweet and Dupree, } 1968 \\
\text { Schneider, 1969 } \\
\text { Varma and Pudney, } 1969 b\end{array}$ \\
\hline
\end{tabular}


Table II. Survey on virus cultivation in mosquito cell lines.

\begin{tabular}{|c|c|c|c|c|}
\hline LINE & VIRUSES TESTED & $\begin{array}{c}\text { VIRUSES } \\
\text { PROPAGATED }\end{array}$ & CPE & AUTHOR \\
\hline \multirow[t]{4}{*}{$\begin{array}{l}\text { Aedes aegypti } \\
\text { (Grace, 1966) }\end{array}$} & JE, MVE & JE, MVE & JE & $\begin{array}{l}\text { Filshie and } \\
\text { Rehacek, } 1968\end{array}$ \\
\hline & YF & YF & & $\begin{array}{l}\text { Converse and } \\
\text { Nagle, } 1967\end{array}$ \\
\hline & $\begin{array}{l}\text { JE, WN, MVE, } \\
\text { Kunjin, Sindbis, SF, } \\
\text { EH, Bebaru, } \\
\text { Kokoberra }\end{array}$ & $\begin{array}{l}\text { JE, WN, MVE, } \\
\text { Kunjin }\end{array}$ & JE & $\begin{array}{l}\text { Rehacek, } \\
1968 a\end{array}$ \\
\hline & $\begin{array}{l}\text { EEE, SLE, JE, } \\
\text { Cache Valley, CE }\end{array}$ & SLE, JE & & $\begin{array}{l}\text { Sweet and } \\
\text { Unthank, } 1969\end{array}$ \\
\hline \multirow[t]{5}{*}{$\begin{array}{l}\text { Aedes albopictus } \\
\text { (Singh, 1967) }\end{array}$} & $\begin{array}{l}\text { Chikungunya, JE, } \\
\text { Sindbis, WN, KFD, } \\
\text { dengue } 1,2,3,4\end{array}$ & $\begin{array}{l}\text { Chikungunya, JE, } \\
\text { Sindbis, WN, } \\
\text { dengue } 1,2,3,4\end{array}$ & \begin{tabular}{|l|} 
JE, \\
WN, \\
dengue \\
$1,2,4$
\end{tabular} & $\begin{array}{l}\text { Singh and } \\
\text { Paul, } 1968 a\end{array}$ \\
\hline & $\begin{array}{l}\text { Sathuperi, AHS, } \\
\text { Batai, Ganjam, } \\
\text { Chandipura, KFD, } \\
\text { Dhori, Kaisodi, } \\
\text { EMC, polio. I., HE, } \\
\text { coxsackie B5 }\end{array}$ & $\begin{array}{l}\text { Sathuperi, Batai, } \\
\text { Ganjam, AHS } \\
\text { Chandipura }\end{array}$ & & $\begin{array}{l}\text { Singh and } \\
\text { Paul, } 1968 b\end{array}$ \\
\hline & CTF & CTF & & $\begin{array}{l}\text { Yunker and } \\
\text { Cory, } 1969\end{array}$ \\
\hline & $\begin{array}{l}\text { JE, SLE, WN, } \\
\text { Langat, Powassan }\end{array}$ & JE, SLE, WN & & $\begin{array}{l}\text { Yunker and } \\
\text { Cory, } 1968\end{array}$ \\
\hline & $\begin{array}{l}\text { WN, Chikungunya, } \\
\text { EEE, SF, VEE, SLE, } \\
\text { YF, VS, CTF, Mo- } \\
\text { doc, CR, SNSF, Lan- } \\
\text { gat, Farallon, Silver- } \\
\text { water, Chenuda, } \\
\text { Johnston Atoll, } \\
\text { Qualyub, Bandia } \\
\text { C 558, URB-TMA } \\
1381\end{array}$ & $\begin{array}{l}\text { WN, Chikungu- } \\
\text { nya, EEE, SF, } \\
\text { VEE, SLE, YF, } \\
\text { VS, CTF }\end{array}$ & WN & Buckley, 1969 \\
\hline
\end{tabular}




\begin{tabular}{|c|c|c|c|c|}
\hline LINE & VIRUSES TESTED & $\begin{array}{c}\text { VIRUSES } \\
\text { PROPAGATED }\end{array}$ & CPE & AUTHOR \\
\hline \multirow[t]{3}{*}{$\begin{array}{l}\text { Aedes aegypti } \\
\text { (Singh, 1967) }\end{array}$} & $\begin{array}{l}\text { Chikungunya, WN, } \\
\text { Sindbis, JE, KFD, } \\
\text { dengue } 1,2,3,4\end{array}$ & $\begin{array}{l}\text { Chikungunya, } \\
\text { WN, Sindbis? }\end{array}$ & & $\begin{array}{l}\text { Singh and } \\
\text { Paul, } 1968 a\end{array}$ \\
\hline & $\begin{array}{l}\text { Sathuperi, Batai, } \\
\text { Ganjam, Kaisodi, } \\
\text { Chandipura, Dhori, } \\
\text { KFD, EMC, polio I., } \\
\text { coxsackie B5, HE }\end{array}$ & Chandipura & & $\begin{array}{l}\text { Singh and } \\
\text { Paul, } 1968 b\end{array}$ \\
\hline & $\begin{array}{l}\text { WN, Chikungunya, } \\
\text { EEE, SF, VEE, SLE, } \\
\text { YF, VS, CTF, } \\
\text { Modoc, CR, SNSF, } \\
\text { Langat, Farallon, } \\
\text { Silverwater, Chenu- } \\
\text { da, Johnston Atoll, } \\
\text { Qualyub, Bandia, } \\
\text { C 558, URB-TMA } \\
1381\end{array}$ & $\begin{array}{l}\text { WN, Chikungunya, } \\
\text { EEE, SF, VEE, } \\
\text { SLE, YF, VS }\end{array}$ & & Buckley, 1969 \\
\hline \multirow{2}{*}{$\begin{array}{l}\text { Aedes aegypti } \\
\text { (Peleg, } 1968 \mathrm{~b} \text { ) }\end{array}$} & EEE, SF, WN & EEE, SF, WN & & Peleg, $1968 b$ \\
\hline & $\begin{array}{l}\text { RNA of WN, FS, } \\
\text { EMC, polio }\end{array}$ & WN, SF & & Peleg, $1968 c$ \\
\hline \multirow{2}{*}{$\begin{array}{l}\text { Culiseta inornata } \\
\quad \text { and } \\
\text { Aedes vexans } \\
\text { (Sweet and } \\
\text { Dupree, 1968) }\end{array}$} & $\begin{array}{l}\text { SLE, EEE, CE } \\
\text { Cache Valley }\end{array}$ & SLE & & $\begin{array}{l}\text { Sweet et al., } \\
1968\end{array}$ \\
\hline & $\begin{array}{l}\text { SLE, EEE, JE, CE, } \\
\text { Cache Valley }\end{array}$ & SLE, JE & & $\begin{array}{l}\text { Sweet and } \\
\text { Unthank, } 1969\end{array}$ \\
\hline
\end{tabular}

Glossary of abreviations used :

JE - Japanese encephalitis; MVE - Murray Valley Encephalitis; YF - Yellow fever ; WN - West Nile; SF - Semliki Forest ; EH - Edge Hill ; SLE - St. Louis Encephalitis ; CE - California Encephalitis ; KFD - Kyasanur Forest Disease ; AHS - African horse sickness; EMC - Encephalomyocarditis ; HE - Mouse-hepato-encephalomyelitis ; CTF - Colorado Tick Fever; VEE - Venezuelan Equine Encephalomyelitis; EEE - Eastern Equine Encephalomyelitis; VS - Vesicular Stomatitis; CR - Cowbone Ridge ; SNSF - Sicilian and Naples sandfly fever. 


\section{Bibliography}

1. BALl (G. H.), 1947. - Attemps to cultivate the mosquito phase of Plasmodium relictum. Am. J. Trop. Med., $27:$ 301-307.

2. - 1948. - Extended persistence of Plasmodium relictum in culture. Am. J. Trop. Med., 28 : 533-536.

3. - 1954. - Prolonged contraction of mosquito digestive tract in vitro with partial development of oocysts of Plasmodium relictum. Exp. Parasitol., 3: 358-367.

4. BanerJee (K.) and Singh (K. R. P.), 1968. - Establishment of carrier cultures of Aedes albopictus cell line infected with arboviruses. Ind. Journ. Med. Res., 56: 812-814.

5. BECKEL (W. E.), 1956. - Maintenance of adult mosquito tissue in a culture medium. Nature, 177: 534-535.

6. Bhat (U. K. M.), and Singh (K. R. P.), 1969. - Structure and development of vesicles in larval tissue culture of Aedes aegypti. Journ. Med. Ent., 6 : 71-74.

7. BRAdFord (S.) and RAMSEy (R. W.), 1949. - Analysis of mosquito tissues for sodium and potassium and development of a physiological salt solution. Fed. Proc., 8: $15-16$

8. Buckley (S. M), 1969. - Susceptibility of the Aedes albopictus and A. aegypti cell lines to infection with arboviruses. Proc. Soc. Exp. Biol. Med., 131: 625-630.

9. Converse (J. L.) and Nagle (S. C.), Jr., 1967. - Multiplication of yellow fever virus in insect cell cultures. J. Virol., 1: 1096-1097.

10. Eagle (H.), 1955. - The specific amino acid requirements of a human carcinoma cell (strain HeLa) in tissue culture. Jour. Exp. Med., 102: 37-48.

11. Filshie (B. K.), Grice (T. D. C.), Poulson (D. F.) and RehaceK (J.), 1967. - Virus like particles in insect cells of three types. J. Inv. Pathology, 9: 271-273.

12. - and ReHACEK (J.), 1968. - Studies of the morphology of Murray Valley Encephalitis and Japanese Encephalitis viruses growing in cultured mosquito cells. Virology, $34: 435-443$.

13. Fujita (N.), Yasui (Y.), Kitamura (S.) and Hotta (S.), 1968. - Cultivation of Japanese encephalitis virus in primary Culex mosquito tissue cultures. Kobe J. Med. Sci., $14: 241-249$.

14. Gavrilov (W.) and Cowez (S.), 1941, - Essai de culture in vitro de tissue de moustiques et d'intestins de lapins adultes infectes. Ann. Parasitol., 18: 180-186.

15. Grace (T. D. C.), 1958. - The prolonged growth and survival of ovarian tissue of the promethea moth (Callosamia promethea) in vitro. J. Gen. Physiol., 41 : 1027-1034.

16. - 1962. - Establishment of four strains of cells from insect tissues grown in vitro. Nature, $195:$ : 788-789.

17. - 1966. - Establishment of a line of mosquito (Aedes aegypti L.) cells grown in vitro. Nature, $211: 366-367$.

18. Gubler (D. J.), 1968. - A method for the in vitro cultivation of ovarian and midgut cells from the adult mosquito. Amer. J. Epidem., 87 : 502-508. 
19. Haines (T. W.), 1958. - Tissue culture of Aedes aegypti cells and its application in studies on the behavior of eastern equine encephalomyelitis virus. Ph. D. Thésis. Univ. Maryland (Diss. Abstr., $20: 1-31$ ).

20. Hoffmann (G.) and KöHLer (G.), 1968. - Haltung von Zeckengeweben in künstlichen Nährmedien. Zeitschr. f. Parasitenkunde, $31: 8$.

21. Johnson (J.W.), 1967. - The growth of Venezuelan equine encephalitis virus in tissue cultures of Aedes aegypti mosquitoes. Dis. Abstract, p. 1-60.

22. - 1969. - Growth of Venezuelan and Eastern equine encephalomyelitis viruses in tissue cultures of minced Aedes aegypti larvae. Amer. J. Trop. Med., 18: 103-114.

23. Kitamura (S.), 1964. - The in vitro cultivation of tissues from the mosquito, Culex pipiens var. molestus. Kobe. J. Med. Sci., 10:85-94.

24. - 1965. - The in vitro cultivation of tissues from the mosquito, Culex pipiens var. molestus. II. An improved culture medium useful for ovarian tissue culture. Kobe, J. Med. Sci., $11: 23-30$.

25. - 1966. - The in vitro cultivation of tissues from the mosquitoes. III. Further studies on the cultivation of ovarian tissues of three mosquito species and the examination of the origin of cells grown in vitro. Kobe J. Med. Sci., 12:63-70.

26. Kordova (N.) and ReHaceK (J.), 1959, - Experimental infection of ticks in vivo and their organs in vitro with filterable particles of Coxiella burneti. Acta. Virol., 3: 201-209.

27. LARSEN (W. P.), 1967. - Growth in an insect organ culture. J. Insect. Physiol., 13 : 613-619.

28. Lüscher (M.), 1947. - A method for observing growing epithelial tissue in Rhodnius prolixus (Hemiptera). Nature, 160: 873-874.

29. - , 1948. - Gewebekultur « in vivo » bei Rhodnius prolixus (Hemiptera), Rev. Suisse Zool., $55: 227-232$.

30. MARTIN (H. M.) and Vidler (B. O.), 1962. - In vitro growth of tick tissues (Rhipicephalus appendiculatus Neumann, 1901). Exp. Parasitol., 12: 192-203.

31. Mitsuhashi (J.) and Maramorosch (K.), 1964. - Leafhopper tissue culture : Embryonic, nymphal, and imaginal tissues from aseptic insects. Contrib. Boyce Thompson Inst., $22: 435-460$.

32. NAGLE (S. C.), Jr., 1969. - Improved growth of mammalian and insect cells in media containing increased levels of choline. Appl. Microb., 17: 318-319.

33. -, Crothers (W. C.) and Hall (N. D.), 1967. - Growth of mo.h cells in suspension in hemolymph-free medium. Appl. Microb., 15: 1497-1498.

34. NAUCK (E. G.) and Weyer (F.), 1941. - Versuche zur Züchtung von Rickettsien in explantiertem Läusegewebe. Zbl. Bakter. I. Orig., 147: 365-376.

35. PAUL (S. D.) and SINGH (K. R. P.), 1969. - Comparative sensitivity of mosquito cell lines, vero cell line and infant mice to infection with arboviruses. Curr. Sci., 38 : 241-242.

36. - Singh (K. R. P.), and Bhat (U. K. M.), 1969. - A study on the cytopathic effect of arboviruses on cultures from Aedes albopictus cell line. Ind. Jour. Med. Res., 57 : 339-348.

37. Peleg (J.), 1965. - Growth of mosquito tissues in vitro. Nature, 206: 427-428. 
38. - 1966. - Growth of Aedes aegypti embryonic cells and tissues in vitro. Experientia, $22: 555-557$.

39. - 1968 a. - Growth of arboviruses in primary tissue culture of Aedes aegypti embryos. Amer. J. Trop. Med. Hyg., $17: 219-223$.

40. - 1968 b. - Growth of arboviruses in monolayers from subcultured mosquito embryo cells. Virology, $35: 617-619$.

41. - $1968 c$. - Behavior of infectious RNA from four different viruses in continuously subcultured Aedes aegypti mosquito embryo cells. Nature, 221: 193-194.

42. - , and Trager (W.), 1963. - Cultivation of insect tissues in vitro and their application to the study of arthropod-borne viruses. Amer. J. Trop. Med. Hyg., 12: 820824.

43. RAGab (H. A), 1948. - The maintenance of the isolated mosquito gut in vitro with the object of studying the development of the malaria parasite. Trans. Roy. Soc. Trop. Med. Hyg., 41: 434.

44. - 1949. - Observations on the isolated gut of the mosquito. Trans. Roy. Soc. Trop. Med. Hyg., $43:$ 225-230.

45. Rehacex (J.), 1958. - Preliminary report on tick tissue culture. Acta Virol., 2 : 253-254.

46. - 1962. - An improved method of tick tissue cultures. Acta Virol., 6: 188.

47. - 1963. - Propagation of tick-borne encephalitis (T.E.) virus in tick tissue cultures. Ann. Epiphyties, 14 : 199-204.

48. - 1965 a. - Preparation of tissue cultures from the tick Hyalomma dromedarii Koch. J. Med. Ent., 2 : 161-164.

49. - 1965 b. - Cultivation of different viruses in tick tissue cultures. Acta Virol., 9: 332-337.

50. - 1968 a. - The growth of arboviruses in mosquito cells in vitro. Acta Virol., 12: 241-246.

51. - , 1968 b. - Persistent infection of mosquito cells grown in vitro with Murray Valley Encephalitis and Japanese Encephalitis virus. Acta Virol., 12:340-346.

52. - and Brezina (R.), 1964. - Propagation of Coxiella burneti in tick tissue cultures. Acta Virol., $8: 380$.

53. -, - and MajersKa (M.), 1968. - Multiplication of rickettsiae in cells in vitro. Acta Virol., 12, 41-43.

54. - and Brzostowski (H. W.), 1969 a. - A tick tissue culture medium based on analyses of tick hemolymph. J. Insect Physiol., 15 : 1431-1436.

55. —, - , $1969 \mathrm{~b}$. - The utilization of amino acids and sugars by tick cells cultivated in vitro. J. Insect Physiol., 15: 1683-1686.

56. - and Kozuch (O.), 1964. - Comparison on the susceptibility of primary tick and chick embryo cell cultures to small amounts of tick-borne encephalitis virus. Acta Virol., $8: 470-471$.

57. - , - 1969. - The use of Hyalomma dromedarii tick tissue cultures for the isolation of tick-borne encephalitis virus from its natural foci. Acta Virol., 13: 253.

58. - and PESEK (J.), 1960. - Propagation of Eastern equine encephalomyelitis (EEE) virus in surviving tick tissues. Acta Virol., $4: 241-245$. 
59. - Rajcani (J.), and Gresikova (M.), 1969. - Relationship of Tribec virus to tick cells and tissues. Acta Virol., $13: 439-442$.

60. SchneIder (I.), 1967. - Cultivation of Plasmodium gallinaceum oocysts in Grace's cell strain of Aedes aegypti (L.). Second Inter. Col. Invert. Tissue Culture Instituto Lombardo: Fondazione Baselli, 247-253.

61. - 1968. - Cultivation in vitro of Plasmodium gallinaceum oocysts. Exp. Parasitol., $22: 178-186$.

62. - 1969. - Establishment of three diploid cell lines of Anopheles stephensi (Diptera : Culicidae). J. Cell Biology, 42 : 603-606.

63. SiNGH (K. R. P.), 1967. - Cell cultures derived from larvae of Aedes albopictus (Skuse) and Aedes aegypti (L.). Curr. Sci., $36:$ 506-508.

64. - and Bнat (U. K. M.), 1969. - Primary cell cultures derived from embryos of Anopheles stephensi Liston. Ind. Journ. Med. Res., 57 : 52-55.

65. - and PAUL (S. D.), $1968 a$. - Multiplication of arboviruses in cell lines from Aedes albopictus and Aedes aegypti. Curr. Sci., 37: 65-67.

66. - , - 1968 b. - Susceptibility of Aedes albopictus and Aedes aegypti cell lines to infection by arbo and other viruses. Ind. Jour. Med. Res., 56: 815-820.

67. Stanley (M. S. M.) and Vaughn (J. L.), 1967. - Marked sensitivity of insect cell lines to fungizone (amphotericin B). J. Insect. Physiol., 13: 1613-1617.

68. Suitor (E. C.), Jr., Chang (L. L.) and Liv (H. H.), 1966. - Establishment and characterization of a clone from Grace's in vitro cultured mosquito (Aedes aegypti L.) cells. Exp. Cell. Res., 44 : 572-578.

69. Suitor (E. C.), Jr. and PAul (F. J.), 1969. - Syncytia formation of mosquito cell cultures, mediated by Type 2 dengue virus. Virology, 38: 482-485.

70. Sweet (B. H.) and Dupree (L. T.), 1968. - Growth of cells derived from Culiseta inorna: $a$ and Aedes vexans in tissue culture. A preliminary note. Mosquito News, 28 : 368-373.

71. - and Unthank (D.), 1969. - Mosquito tissue culture: A tool for the arbovirologist. Presented at American Society for Microbiology, South Central Branch Meeting, Natchitoches, La., March 22, 1969.

72. - , - and Polise (F.), 1968. - Attempts at propagation of several arboviruses in two new mosquito tissue culture cell lines. Presented at American Society of Tropica! Medicine and Hygiene, Atlanta, Ga., October 30-November 1, 1968.

73. Trager (W.), 1938. - Multiplication of the virus of equine encephalomyelitis in surviving mosquito tissues. Amer. J. Trop. Med., 18:387-393.

74. - , 1959. - Tse-tse fly tissue culture and the development of trypanosomes to the infective stage. Ann. Trop. Med. Parasitol., 53: 473-491.

75. Vago (C.) and Chastang (S.), 1960. - Culture de Borrelinavirus dans les organes d'insectes en survie. C.R. Acad. Sci. (Paris), 251: 903-905.

76. - and Flandre (O.), 1963. - Culture prolongée de tissu d'insectes et de vecteurs de maladies en coagulum plasmatique. Ann. Epiphyties, 14: 127-139.

77. Varma (M. G. R.), and Pudney (M.), 1967. - The culture of embryonic cells from the bug Triatoma maculata (Erickson) (Hemiptera: Reduviidae). Exp. Cell. Res., 45 : 671-675. 
78. - -, 1969 a. - Tick cell culture : A review of recent work. (In press).

79. - - - $1969 \mathrm{~b}$. - The growth and serial passage of cell lines from Aedes aegypti (L.) in larvae in different media. J. Med. Ent., 6: 432-439.

80. - and Wallers (W.), 1965. - An improved method for obtaining, in vitro, uniform cell monolayer sheets from tissues of the tick Hyalomma dromedarii (Ixodidae). Nature, London, 208: 602-603.

81. WeYER (F.), 1952. - Explantationsversuche bei Läusen in Verbindung mit der Kultur von Rickettsien. Zbl. Bakt. Orig. I., 159: 13-22.

82. Wood (D. E.) and SuIToR (E. C.), Jr., 1966. - In vitro development of microfilariae of Macacanema formosana in mosquito cell culture. Nature, $211: 868-870$.

83. WyatT (S. S.), 1956. - Culture in vitro of tissue from the silkworm, Bombyx mori L. J. Gen. Physiol., 39: 841-852.

84. YUNKer (C. E.) and CORY (J.), 1965. - Effectiveness of refrigerated nymphs in tick tissue culture experiments. J. Parasitol., 51: 686.

85. - , - , 1967. - Growth of Colorado Tick Fever (CTF) virus in primary tissue cultures of its vector Dermacentor andersoni Stiles (Acarina: Ixodidae), with notes on tick tissue culture. Exp. Parasitol., 20: 267-277.

86. —, - , 1968. - Growth of some group B arboviruses in two established insect cell lines. Proceedings, Twenty-third Annual International Northwest Conference on Diseases in Nature Communicable to Man., p. 79-82.

87. - , - 1969. - Colorado Tick Fever Virus: Growth in a mosquito cell line. J. Virol., 3: 631-632.

88. - , VAughn (J. L.) and CORY (J.), 1967. - Adaptation of an insect cell line (Grace's Antheraea cells) to medium free of insect hemolymph. Science, $155: 1565-1566$. 